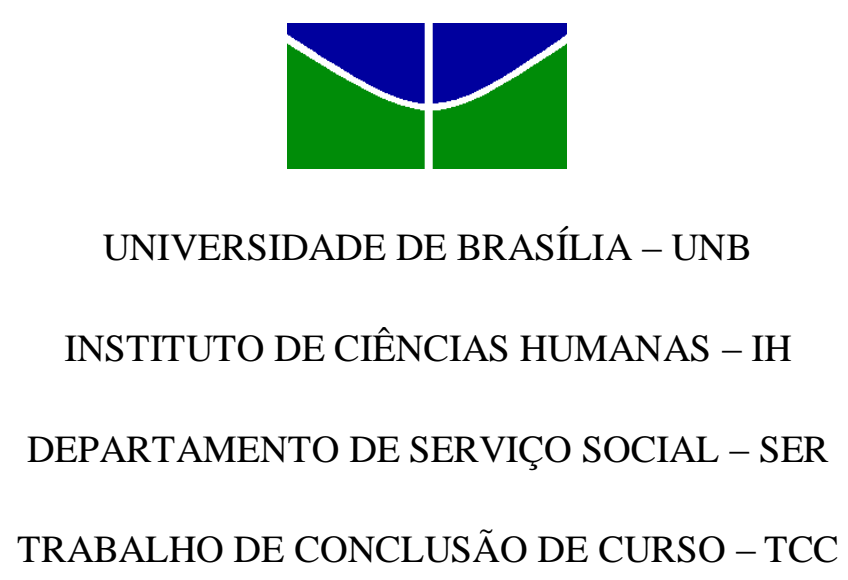

ANDRÉIA DA CRUZ

\title{
Assédio Sexual e Moral no trabalho
}

Um estudo acerca da legislação no Brasil

Orientadora: Silvia Cristina Yannoulas 


\section{ANDRÉIA DA CRUZ}

\section{Assédio Sexual e Moral no Trabalho}

Um estudo acerca da legislação no Brasil

Trabalho de Conclusão de Curso apresentado ao Departamento de Serviço Social do Instituto de Ciências Humanas da Universidade de Brasília como requisito parcial para a obtenção do grau de Assistente Social.

Orientadora: Professora Dra. Silvia Cristina Yannoulas

Brasília

2010 


\section{ANDRÉIA DA CRUZ}

\section{Assédio Sexual e Moral no Trabalho}

Um estudo acerca da legislação no Brasil

Trabalho de Conclusão de Curso apresentado ao Departamento de Serviço Social do Instituto de Ciências Humanas da Universidade de Brasília como requisito parcial para a obtenção do grau de Assistente Social.

Aprovado em 01 de Setembro de 2010

\section{BANCA EXAMINADORA}

Professora Doutora Silvia Cristina Yannoulas - Professora do Departamento de Serviço Social da Universidade de Brasília

\footnotetext{
Professora Doutora Neuza de Farias Araújo - Professora do Departamento de Serviço Social da Universidade de Brasília
}

Assistente Social Anabelle Carrilho Costa - Assistente Social da Eletronorte 
Dedico este trabalho: aos meus pais, Ercília e Luis; a minha tia, Rosenir; aos meus amigos, em especial, Alice; a meu noivo, Aluisio. 


\section{AGRADECIMENTOS}

Agradeço primeiramente a Deus, por me dar força e por me iluminar durante todos esses anos de graduação.

Agradeço aos meus pais, em especial, minha mãe, por todo apoio, incentivo e dedicação que recebi ao longo desses difíceis anos na Universidade.

Agradeço a minha tia Rosenir, por acreditar no meu potencial e por ter investido em mim quando foi preciso.

Agradeço ao meu noivo, pelo companheirismo, compreensão e por todo apoio que foi fundamental para a superação dos momentos mais complicados da minha graduação.

Sou grata a minha família em geral por estar sempre ao meu lado e por presenciar mais essa conquista na minha vida.

Agradeço aos meus amigos do curso de Serviço Social, em especial a Alice, pela amizade e por compartilhar comigo momentos ímpares vivenciados nessa Universidade, por se fazer importante em todas as áreas da minha vida.

Agradeço a todos os professores e funcionários do Departamento de Serviço Social da Universidade de Brasília pelo auxílio fornecido sempre que necessário.

Sou grata a todos que contribuíram para a execução deste trabalho; em especial a professora Silvia Cristina Yannoulas pela sábia condução desta pesquisa, pelas importantes orientações e por toda paciência. 
"É pelo trabalho que a mulher vem diminuindo a distância que a separava do homem, somente o trabalho poderá garantir-lhe uma independência concreta." Simone de Beauvir "Seja qual for seu sonho - comece. Ousadia tem genialidade poder e magia." Johann Wolfgang Von Goethe 


\section{RESUMO}

A presente pesquisa teve por objetivo investigar os fatores que foram fundamentais no surgimento da Lei que dispõe sobre o assédio sexual, Lei de $n^{\circ}: 10.224 / 01$, e Projeto de Lei que dispõe sobre o assédio moral, Projeto de Lei de $n^{\circ}: 2.369 / 03$. Partiu-se então do seguinte problema: Identificar os fatores que foram fundamentais para a aprovação da Lei $\mathrm{n}^{\mathbf{0}}$ : 10.224/01 e para o surgimento do projeto de Lei ${ }^{\circ}: 2.369 / 03$, levantando-se como hipótese: A denúncia de vítimas de assédio sexual e de assédio moral foi fundamental para surgimento dessa Lei e projeto de Lei. Com o intuito de investigar a procedência dessa hipótese foram feitas análise documental e 7 entrevistas semi-estruturadas com questões abertas a pessoas que trabalham nessa área e/ou acompanharam as discussões que aconteceram na época de surgimento da referida Legislação. Constatou-se com este estudo que diversos foram os fatores que contribuíram para o surgimento das referidas legislações. Contudo, percebe-se pela fala dos entrevistados, fatores que tiveram destaque: a participação dos movimentos sociais, do movimento feminista e do movimento de mulheres.

Palavras-chave: assédio sexual; assédio moral; divisão sexual do trabalho. 


\section{LISTA DE TABELAS}

Tabela 1 - Comparação entre a Lei de no: 10.224/01 e Projeto de Lei de no: 2.369/03.....

.67 


\section{LISTA DE ABREVIATURAS E SIGLAS}

ABBC- Associação Brasileira de Bancos

AATP - Associação dos juízes Trabalhistas de Pernambuco

CCJ - Comissão de Constituição e Justiça

CF - Constituição Federal

CIEE - Centro de Integração Empresa Escola

CFM - Conselho Federal de Medicina

CLT - Consolidação das Leis Trabalhistas

CNTI - Confederação Nacional dos Trabalhadores da Indústria

IH - Instituto de Ciências Humanas

IPEA - Instituto de Pesquisa Econômica Aplicada

MPF - Ministério Público Federal

MPT - Ministério Público do Trabalho

TEM - Ministério do Trabalho e Emprego

OEA - Organização dos Estados Americanos

OIT - Organização Internacional do Trabalho

ONG - Organização Não Governamental

PEA - População Economicamente Ativa

PE - Pernambuco

PTCC - Projeto de Trabalho de Conclusão de Curso

SER - Departamento de Serviço Social

SPM - Secretaria de Políticas para as Mulheres 
SPTER - Seção de Políticas de Trabalho, Renda e Economia Solidária SRT - Superintendência Regional do Trabalho

STF - Supremo Tribunal Federal

TCC - Trabalho de Conclusão de Curso

TCLE - Termo de Consentimento Livre Esclarecido

TRT - Tribunal Regional do Trabalho

UNB - Universidade de Brasília 


\section{SUMÁRIO}

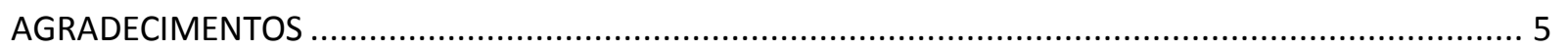

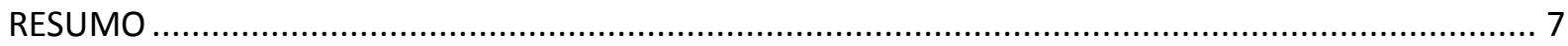

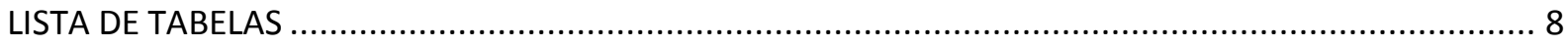

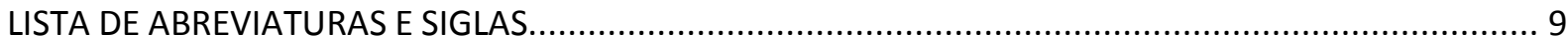

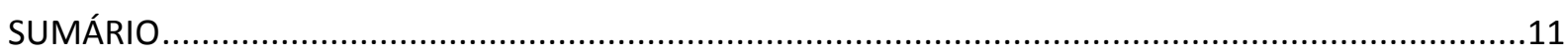

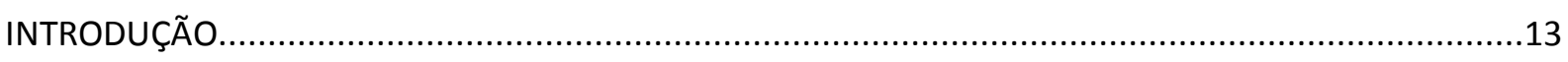

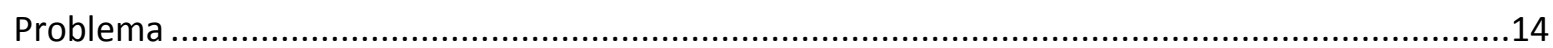

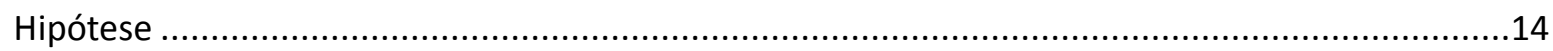

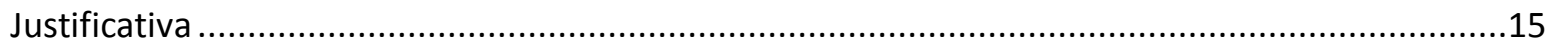

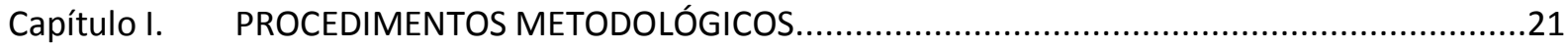

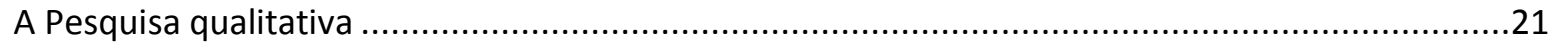

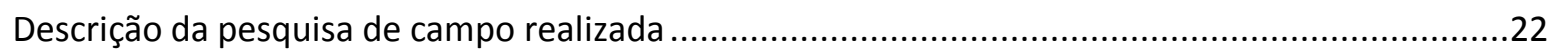

Capítulo II. RELAÇÕES DE GÊNERO E DIVISÃO SEXUAL DO TRABALHO: O CONTEXTO DOS ASSÉDIOS 29

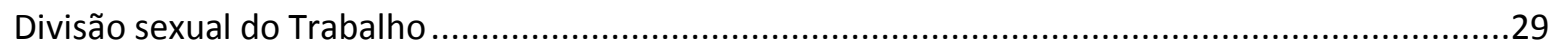

As barreiras enfrentadas pelas mulheres no mercado de trabalho ................................................33

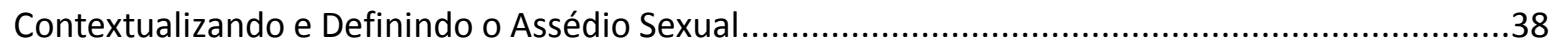

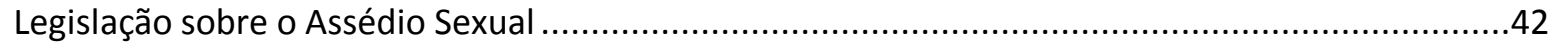

As opiniões das entrevistadas e do entrevistado sobre o assédio sexual......................................44

Uma breve reflexão acerca de algumas reportagens da internet sobre assédio sexual...................49

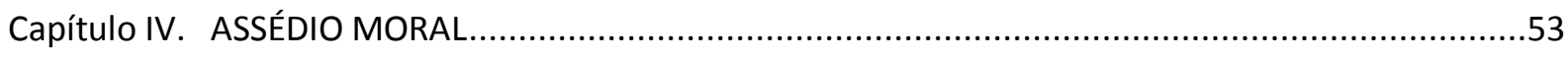

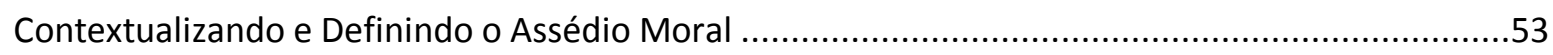

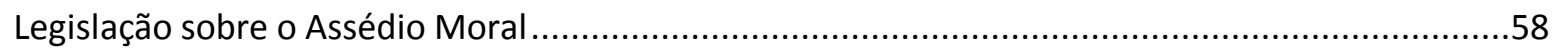

As opiniões das entrevistadas e do entrevistado sobre o assédio moral .....................................60

Uma breve reflexão acerca de algumas reportagens da internet sobre assédio moral ..................62

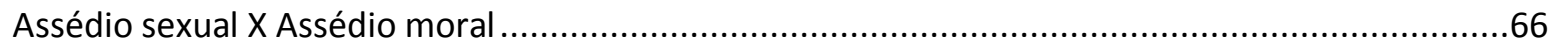




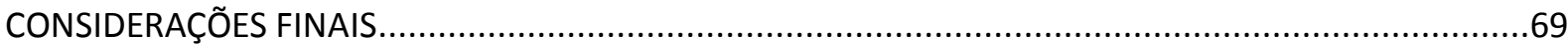

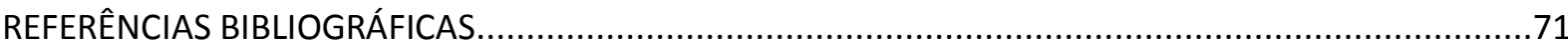

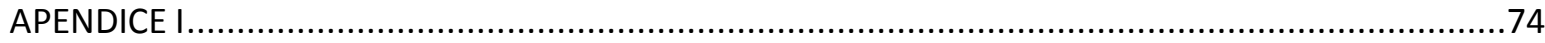

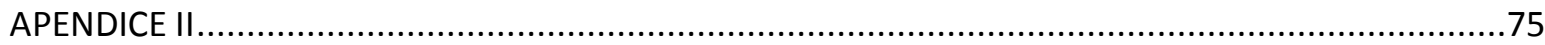

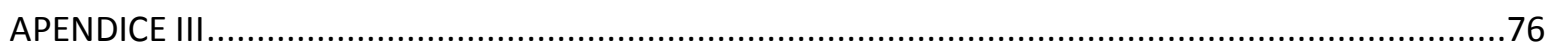

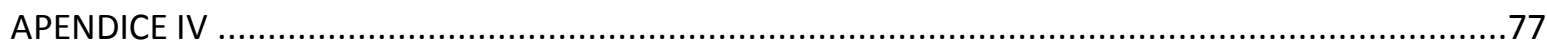

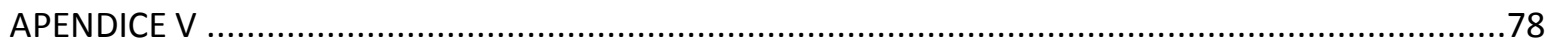




\section{INTRODUÇÃO}

A temática das relações de gênero na sociedade traz à tona uma multiplicidade de discussões que se fossem abordadas por esse trabalho de conclusão conduziriam a um infindável debate. Não menosprezando a importância desse debate perpassando por suas múltiplas variáveis, mas considerando o tempo e o espaço aqui disponíveis, centra-se este trabalho de conclusão sobre a temática das mulheres em um dos seus âmbitos, o trabalho.

As perspectivas de gênero que a sociedade criou e da divisão sexual do trabalho baseado numa cultura patriarcal e machista fazem com que as mulheres enfrentem inúmeras dificuldades no mercado de trabalho. Dentre esse contexto de dificuldades que as mulheres encontram no âmbito do trabalho se encontra o assédio sexual e moral.

O assédio sexual e moral afetam todos os trabalhadores, mas atingem majoritariamente as trabalhadoras, principalmente no que se refere ao assédio sexual. Esse fenômeno do assédio não é novo, embora o assédio moral tenha conseguido visualização somente a partir da década de 90, sendo que, não há legislações no Brasil que protejam os dois tipos de assédio, o sexual e o moral.

A Lei que criminaliza o assédio sexual é relativamente nova se for considerado a existência do problema e o reconhecimento que alguns países fizeram da questão, nos Estados Unidos o assédio é reconhecido desde 1976. No Brasil a primeira Lei Federal que efetivamente criminalizou o assédio sexual foi a Lei no: 10.224, aprovada em 2001.

No que diz respeito a legislações que protegem os trabalhadores (as) vários países já possuem leis severas sobre os crimes de assédio moral, como Alemanha, Itália, França, Estados Unidos, Suíça.

O Brasil ainda não possui nenhuma Lei Federal que prevê punição específica para crimes de assédio moral, embora haja atualmente vários projetos de Lei tramitando no Congresso Nacional e várias Leis estaduais que regulamentam essa problemática. Um desses projetos de Lei é o n. : 2.369/03 que tipifica o assédio moral e prevê a responsabilização não somente do assediador, mas também, do empregador.

Este trabalho de conclusão tem como tema então estudar o surgimento das referidas legislações de proteção dos (as) trabalhadores (as). A Lei $\mathrm{n}^{\mathrm{o}}$ : 10.224/01, que altera o DecretoLei n ${ }^{\mathrm{o}}$ 2.848, de 7 de dezembro de 1940 - Código Penal, para dispor sobre o crime de assédio sexual e projeto de lei $2.369 / 03$ que define o assédio moral. O estudo do surgimento da Lei ${ }^{\text {o: }}$ : 
10.224/01 e do projeto de Lei ${ }^{\text {o }}: 2.369 / 03$ compreende o período que vai dos anos de 1940 até 2010, e o espaço geográfico nacional, ou seja, o Brasil.

\section{Problema}

No caso do assédio sexual, a Lei $n^{\circ}$ : 10.224/01 introduziu no Código penal (DecretoLei $\mathrm{n}^{\circ}: 2.848$ de 1940), o delito de assédio sexual com a seguinte redação:

Art. 216-A. Constranger alguém, com o intuito de obter vantagem ou favorecimento sexual, prevalecendo o agente da sua condição de superior hierárquico ou ascendência inerentes ao exercício de emprego. Cargo ou função: pena - detenção, de 1(um) a 2 (dois) anos.

Em se tratando do assédio moral, o projeto de Lei $n^{\circ}: 2.369 / 03$ não só normatiza o assédio moral como prevê responsabilidade do empregador, estando este sujeito à multa caso não cumpra com as suas obrigações de tentar cuidar do bem estar dos seus empregados. Ambas as leis se relacionam diretamente com a problemática de gênero no ambiente de trabalho, sendo as principais vítimas desses crimes as trabalhadoras.

Mesmo considerando que o Brasil evoluiu em matéria de defesa e reconhecimento dos direitos das mulheres, há que se refletir que o legislativo brasileiro agiu um pouco atrasado na regulamentação desses fenômenos se considerarmos outros países.

Conhecendo essa debilidade do país no que se refere ao reconhecimento dos direitos femininos e proteção desse seguimento no ambiente do trabalho, torna-se imperativo solucionar o seguinte problema:

- Identificar os fatores que foram fundamentais para a aprovação da Lei $n^{\circ}$ : 10.224/01 e para o surgimento do projeto de Leis $n^{\circ}: 2.369 / 03$.

Para isso parte-se da seguinte pergunta:

- O que foi fundamental para a aprovação da Lei 10.224/01 e para o surgimento do projeto de Lei 2.369/03?

Hipótese 
Conhecendo a história do surgimento dessas leis, descobrindo o que foi determinante no processo de surgimento e investigando possíveis casos e situações, espera-se visualizar melhor o que tem sido fundamental para o surgimento de leis que protegem o segmento feminino no âmbito do trabalho.

Tomando como exemplo a história da criação da Lei Maria da Penha, que protege as mulheres contra a violência doméstica, na qual a denúncia da Maria da Penha Maia Fernandes, vítima de violência doméstica por parte de seu companheiro, foi fundamental para a criação da Lei, junto com outros fatores como a ativa participação de movimentos feministas, espera-se constatar que o surgimento da Lei $\mathrm{N}^{\mathrm{o}}$ : $10.224 / 01$ e projeto de lei $\mathrm{n}^{\mathrm{o}}$ : 2.369/03 se relacionem as denúncias de mulheres que foram vítimas ou a própria luta do movimento de mulheres. Sendo assim, a hipótese é:

- “A denúncia de vítimas de assédio sexual e de assédio moral foi fundamental para surgimento dessa Lei e projeto de Lei."

\section{Justificativa}

A importância de estudar esse tema se relaciona ao fato de que o (a) profissional de Serviço Social lida constantemente, no seu dia-a-dia de trabalho, com essas temáticas de violência e de desrespeitos aos direitos sociais fundamentais de determinados segmentos.

A fim de atuar na defesa desses segmentos torna-se imperativo conhecer as legislações que prevêm os direitos da população, com o intuito não somente de elaborar uma estratégia de ação, mas também, de lutar para que certas lacunas no campo legislativo sejam supridas. Como é o caso do Assédio moral, que ainda não é regulamentado por Lei, mas que está em processo de regulamentação. No caso deste Trabalho de Conclusão de Curso, especificamente, o propósito foi o de tecer uma ponte entre as políticas sociais, as políticas de gênero, e o direito ao trabalho.

O direito ao trabalho está previsto na nossa Carta Magna, a Constituição Federal de 1988 (CF 1988), no Título II - Dos Direitos e Garantias Fundamentais, mais precisamente, no Capitulo II - Dos Direitos Sociais. O artigo sexto desse Capítulo prevê:

"São direitos sociais a educação, a saúde, o trabalho, a moradia, o lazer, a segurança, a previdência social, a proteção à maternidade e à infância, a assistência aos desamparados, na forma desta Constituição." (CONSTITUIÇÃO FEDERAL DE 1988) 
Considerando que o Serviço Social é uma profissão diretamente ligada à defesa dos direitos dos sujeitos e considerando ainda que o direito ao trabalho se configura como um direito fundamental da pessoa, torna-se evidente a relação entre esta profissão e o campo do trabalho.

Ter um estudo acerca do surgimento dessas legislações é importante porque proporciona conhecimentos sobre a realidade social de muitos daqueles que são público alvo da ação do Serviço Social. Essas informações contribuem para uma melhor atuação do (a) Assistente Social junto ao trabalhador (a), seja no caso de um atendimento, seja no caso de uma formulação de política pública, seja no caso de qualquer outra ação.

A temática de gênero sempre foi algo que me despertou muito interesse, mesmo antes de entrar na Universidade. Durante a minha trajetória na Universidade comecei a ter mais contato com a área, especificamente, no quarto e quinto semestres, cursando as disciplinas sobre Pesquisa em Serviço Social 1 com a professora Neuza Farias e Pesquisa em Serviço Social 2 com a Débora Diniz. Na ocasião, abordamos a legislação que protege as mulheres contra violência doméstica, estudando o surgimento da Lei $\mathrm{n}^{\mathrm{o}} 11.340 / 06$, mais conhecida como Lei Maria da Penha. O uso do verbo no plural se justifica porque o trabalho foi realizado em grupo, éramos uma equipe de 5 participantes e cada uma utilizava uma técnica diferente de coleta de dados.

A realização dessa pesquisa despertou o interesse para um ponto que antes não era visualizado com tanta clareza, que é o surgimento das Leis que protegem as mulheres contra atos e processos de violência. Foi possível perceber como esse processo é complexo e que existem fatores que são determinantes para o surgimento de uma lei.

Ao pensar no fato de que a profissão Serviço Social reflete e tem um significado próprio dentro do modelo de produção capitalista percebe-se a importância na formação de um (a) assistente social de estudar a categoria trabalho. Um (a) assistente social lidará no seu dia-a-dia com as seqüelas do sistema capitalista, com as conseqüências da exploração do capital sobre a mão-de-obra do (a) trabalhador (a), com as desigualdades, com a injustiça social que esse sistema de produção traz na sua matriz básica. É de fundamental importância que o/a futuro (a) assistente social tenha uma postura crítica a respeito da sua prática e a respeito do seu papel nesse contexto, para que assim, ele/ela não acabe agindo em favor do capital, ao invés de defender o (a) trabalhador (a), que é a classe pela qual luta o/a assistente social. Para adquirir essa consciência crítica sobre a sua atuação é necessário estudar a categoria do trabalho e tudo que o envolve nesse contexto. 
Nos dias atuais o Serviço social vive um momento de ampliação do debate para outras questões sociais que não se relacionam diretamente com a tradicional contradição entre capital e trabalho, entre a divisão da sociedade em classes. O Serviço Social começa a se debruçar sobre outras problemáticas que não estão necessariamente imbricadas na teoria marxista, tendo em vista, o seu caráter emergente contemporâneo, essas problemáticas se relacionam a questões de gênero, raça e meio ambiente, entre outras importantes. A questão social atualmente revela desigualdades não somente econômicas e políticas, mas também, culturais, perpassadas pelas diferenças nas relações entre os homens e as mulheres e nas relações étnico-raciais. Diante desse contexto de mudanças é importante para o trabalho das futuras assistente sociais estarem cientes dessas novas problemáticas e estarem preparadas para lidar com esse olhar crítico diferenciado. Nesse sentido é que se busca cada vez mais uma interlocução do Serviço Social com outras áreas do conhecimento como a Sociologia e o Direito.

O fato de se abrir o olhar para novas questões possibilita um diálogo melhor com outros saberes. O Serviço Social para compreender melhor as atuais transformações pelas quais o mercado de trabalho vem passando se apóia bastante na Sociologia do trabalho, para visualizar de maneira mais eficiente os reflexos das mudanças que estão ocorrendo no mercado de trabalho sobre os direitos da classe operária busca conhecimento no direito trabalhista. Assim prossegue fazendo uma interlocução com outras ciências para o aperfeiçoamento da própria prática profissional.

A divisão sexual do trabalho, forma de divisão do trabalho decorrente das relações sociais entre os sexos, que existe na sociedade, contribui sobremaneira para os processos de discriminação que recaem sobre as mulheres. É por meio da divisão sexual do trabalho, que foi estabelecida nessa sociedade patriarcal, que as pessoas atribuem valores e hierarquias diferentes ao trabalho realizado pelos homens e ao trabalho realizado pelas mulheres. As mulheres ganham menos que os homens exercendo a mesma função, trabalham em empregos mais precários, tem mais dificuldade de entrar no mercado de trabalho.

Por isso é necessário que existam legislações de proteção às mulheres em diversos campos, principalmente no trabalho. O combate a discriminação é tão importante que está previsto na Constituição Federal de 1988, nos seus artigos 5º inciso I:

"I-homens e mulheres são iguais em direitos e obrigações, nos termos desta Constituição" (CONSTITUIÇÃO FEDERAL DE 1988)

$\mathrm{E}$ artigo $7^{\circ}$, inciso $\mathrm{XXX}$ : 
"XXX- proibição de diferença de salários, de exercício de funções e de critério de admissão por motivo de sexo, idade, cor ou estado civil." (CONSTITUIÇÃO FEDERAL DE 1988)

A fim de que essas legislações sejam colocadas em prática e que as lacunas existentes nas mesmas sejam preenchidas é necessário estudos acerca dessa realidade.

A produção deste trabalho de conclusão de curso pode contribuir também ao conhecimento científico, principalmente para uma visualização melhor das consequiências das desigualdades nas relações de poder no mundo do trabalho, e como as legislações têm captado essa problemática criando mecanismos de proteção para a parte menos favorecida.

Ao elaborar um trabalho de conclusão sobre essas temáticas o conhecimento científico pode se beneficiar com mais estudos sobre o mundo do trabalho, contudo sob a ótica do gênero, que é uma problemática que vem se mostrando na contemporaneidade um fator de extrema importância para todas as áreas do saber, das Ciências humanas às Ciências Biológicas.

A medicina volta e meia se vê obrigada a se debruçar sobre questões do mundo do trabalho, para tentar compreender o que está acontecendo com os trabalhadores que estão adoecendo sem uma causa visível. A Sociologia se vê obrigada a estudar as manifestações de discriminação no mundo do trabalho e o porquê da sociedade não conseguir romper com essas barreiras tão primitivas.

A economia, que sempre estudou o mundo do trabalho, nunca se empenhou tanto como agora em perceber as particularidades de gênero no mundo do trabalho, justamente por que os problemas trazidos pelo assédio moral e sexual têm ultrapassado as portas das empresas.

Em diversas áreas do conhecimento está se fazendo perceber a importância de estudar essa temática velha, mas com visualização relativamente recente, principalmente no que se trata do assédio moral. Um trabalho de pesquisa nessa temática facilitará a diferenciação entre essas duas formas de atos criminosos que apresentam uma relação às vezes intrínseca e uma diferenciação que se percebe por sutilezas.

A colaboração ao aporte do conhecimento cientifico pode proporcionar a esse conhecimento mais possibilidades de subsidiar órgãos públicos na prevenção e tratamento dessa problemática. A Secretaria de Políticas para as Mulheres (SPM), por exemplo, terá uma base maior de informações para pensar suas formas de atuação e terá mais conteúdo para divulgar, para conscientizar e para fiscalizar pontos que envolvem esse tema. 
Conhecer a origem das leis, de quais pontos partiram, de quais fatores surgiram, possibilitará uma maior visibilidade da causa para maior produção de artigos científicos e possibilitará, posteriormente, maiores conquistas nesse âmbito.

Este estudo é importante para a sociedade por permitir uma maior visualização da importância das denúncias de vítimas desses crimes, da atuação do movimento de mulheres na efetivação/concretização dos direitos desse segmento e da importância de movimentos sociais na articulação de direitos de determinado segmento com o poder público.

Este estudo é importante em matéria de políticas sociais por poder proporcionar informações acerca da realidade social desse público o que mostra a necessidade de melhores políticas sociais para este segmento, ou então, um melhor direcionamento das mesmas.

Os órgãos públicos destinados a promover políticas públicas, se forem informados, terão uma base melhor para atuar e saberão como fazer uso dos recursos destinados para esse fim, utilizando com racionalidade os recursos advindos da contribuição da sociedade.

A sociedade necessita tomar conhecimento das especificidades desses fenômenos para que assim possa combatê-los de forma eficaz. Como pode a sociedade combater o assédio sexual e o assédio moral nos ambientes de trabalho se além de não ter legislação específica para as duas formas de crimes, como é o caso do assédio moral, não se sabe ao certo a sutil diferença entre os dois.

Partindo do objetivo de debater o surgimento das referidas leis, Lei $\mathrm{n}^{\mathrm{o}}$ : 10.224/01 e Projeto de lei $\mathrm{n}^{\mathrm{o}}$ : $2.369 / 03$, este trabalho se estrutura em quatro capítulos. No primeiro capítulo fala-se um pouco sobre a pesquisa que foi realizada, o tipo de pesquisa que foi escolhido, o porque dessa escolha, como foi colocada em prática e os encontros e desencontros pelos quais passou esta pesquisadora na sua ida a campo.

No segundo capítulo aborda-se a discussão sobre a divisão sexual do trabalho, perpassando os seus conceitos, sua origem, sua evolução e suas implicações no mundo do trabalho para o sexo feminino. Reflete-se também neste capítulo sobre as muitas barreiras que as mulheres enfrentam no mercado de trabalho, visualizadas na maior parte do tempo como conseqüência da própria divisão sexual do trabalho.

No terceiro capítulo debate-se sobre a problemática do assédio sexual, suas origens, suas causas, as formas de agir do agressor sobre a população alvo, que são com freqüência as mulheres, e suas definições. Reflete-se sobre a legislação brasileira a respeito do tema e as opiniões das entrevistadas e do entrevistado sobre esse fenômeno e os fatores que contribuíram para o surgimento da legislação brasileira que criminaliza o assédio sexual. É 
também objeto deste capítulo a forma como a mídia repercute esse assunto que degrada o mundo do trabalho.

No quarto capítulo aborda-se a questão do assédio moral no mundo do trabalho, seu nascimento, a consolidação do conceito no país, suas causas, as diversas maneiras do agressor cometer essa prática cruel e as definições do termo assédio moral. Debate-se acerca da legislação brasileira, das leis e artigos que podem ser utilizados para coibir essa prática, tendo em vista que o problema não possui uma Lei que o criminalize nacionalmente. Ainda se discute neste capitulo as opiniões das entrevistadas e do entrevistado a respeito dos fatores que contribuíram para a proposição do projeto de Lei $n^{\circ}: 2.369 / 03$ que dispõe sobre o assédio moral e se encontra em tramitação na Câmara dos Deputados. Por fim, reflete-se a forma como a mídia manifesta o fenômeno do assédio moral no trabalho. 


\title{
Capítulo I. PROCEDIMENTOS METODOLÓGICOS
}

\author{
A Pesquisa qualitativa
}

O tipo de pesquisa utilizado neste trabalho, a pesquisa qualitativa, está presente em uma série de disciplinas, envolvendo as ciências humanas e sociais e fazendo uso de uma variedade de métodos de investigação para estudar determinado fenômeno. $\mathrm{O}$ fato de ser qualitativa indica uma partilha com pessoas, fatos e locais que se relacionam ao objeto de pesquisa (Chizzotti, 2003). Assim, a pesquisa qualitativa, não tem por objetivo enumerar ou medir eventos ou dados, mas sim obter significados do convívio de muitos fatores, traduzindo tudo em um texto que explora o seu objeto de pesquisa.

De acordo com Neves (2003), a pesquisa qualitativa possui um amplo foco de interesse e se diferencia dos métodos quantitativos em sua perspectiva, pois, dela objetiva-se conseguir dados descritivos em um contato direto com a situação que é objeto de estudo. Por isso é comum no ramo das pesquisas qualitativas se buscar compreender os fenômenos de acordo com a perspectiva dos colaboradores de pesquisa.

Para Gunter (2006), a pesquisa qualitativa prefere estudar relações complexas ao invés de explicá-las por meio do isolamento de variáveis. Assim, as pesquisas qualitativas levam os entrevistados (as) a pensarem livremente sobre algum objeto proposto, podendo fazer emergir aspectos subjetivos que atingem motivações, conscientes ou não, de maneira espontânea. Buscam-se os entendimentos sobre alguma questão e abre-se espaço para a interpretação, criando assim consensos ou mesmo novos posicionamentos sobre o objeto inicialmente proposto.

Quando se opta por utilizar a pesquisa qualitativa o objetivo é durante a obtenção das informações identificar as questões referentes ao objeto de estudo e entender porque essas questões são importantes. Assim, ajuda a determinar quais as idéias que geram reações significativas, sendo útil tanto em situações que envolvam desenvolvimento de novas idéias quanto em situações que aperfeiçoam idéias já conhecidas. Por esse motivo optou-se por esse tipo de pesquisa neste trabalho, por ela permitir que se entendam porque determinadas variáveis são importantes em um determinado contexto.

A pesquisa em Serviço social se constitui de um importante instrumento de construção de conhecimento e de consolidação da própria prática profissional. De acordo com Bourguignon (2007) têm contribuído para muitos avanços em diversas áreas da ação 
profissional, na questão das políticas públicas, no combate as expressões da questão social e até na consolidação do projeto ético-político da profissão. Infelizmente, de acordo com a autora, a tradição da pesquisa se encontra ainda muito limitada ao âmbito da Universidade, pois, há uma tendência de se pensar que a produção de conhecimento é matéria somente dos docentes. Essa mudança deve ser feita principalmente pelo movimento da própria realidade.

Bourguignon (2007) explica que a particularidade da pesquisa em Serviço Social se dá pela natureza da pesquisa de ser um meio de construção de conhecimento que é comprometido com as demandas da profissão e com seu enfrentamento. Para esta autora, a pesquisa é constitutiva e constituinte do Serviço Social. Constitutiva por que a prática da profissão se baseia na relação teoria e prática, fazendo necessário para a atuação profissional a compreensão dos fenômenos sociais para fundamentar a intervenção. Constituinte porque os avanços obtidos na profissão mobilizam a reconstrução da própria prática profissional.

Outro ponto importante da pesquisa em Serviço Social, de acordo com Bourguignon (2007) é a preocupação em manter a centralidade dos sujeitos. Os procedimentos metodológicos hoje necessitam preservar a centralidade do sujeito porque as ações da profissão são pautadas nas demandas dos usuários que se expressam por meio de suas histórias. Nesse sentido, o Serviço Social precisa produzir um saber que reconheça os usuários dos serviços no intuito de intervir nas realidades dos mesmos sem tirar-lhes a autonomia.

O último ponto que essa autora ressalta é a preocupação que o Serviço Social tem como o retorno e o alcance social das suas pesquisas. Pelo fato de o Serviço Social ser uma profissão que intervêm diretamente nas condições de vida do cidadão existe essa preocupação como o retorno e o alcance das pesquisas, no sentido de retornar a essa realidade que se obteve informações a produção do conhecimento transformando da melhor forma possível esta mesma realidade. ${ }^{1}$

Descrição da pesquisa de campo realizada

A pesquisa realizada teve por objetivo principal conhecer a história do surgimento da Lei 10.224/01 e projeto de Lei 2.369/03, e para tanto, utilizou o método de pesquisa

\footnotetext{
${ }^{1}$ Seguindo essa preocupação do Serviço social com o retorno da pesquisa, este trabalho será enviado em formato Pdf para os entrevistados e também há a intenção de se transformar o mesmo em artigo científico e publicá-lo.
} 
qualitativo. O método em questão se enquadrou melhor aos objetivos da pesquisa por não se amparar exclusivamente em dados estatísticos, mas principalmente, em fatos e fenômenos que convivem e interagem entre si, produzindo significados próprios e dinâmicos.

O primeiro momento da pesquisa consistiu em fazer um levantamento bibliográfico a fim de se tomar conhecimento das questões que envolviam o tema tratado, dos principais autores que abordavam o tema, da contextualização do objeto de estudo. Esta primeira fase resultou na elaboração do Projeto de Trabalho de Conclusão de Curso (PTCC), no qual se levantou o problema de pesquisa, a justificativa do projeto, o referencial teórico inicial, uma proposta de metodologia para esta pesquisa e os resultados esperados. Esta fase inicial se deu no período do segundo semestre de 2009.

A pesquisa de campo foi realizada no período de maio a agosto de 2010. As técnicas utilizadas foram: pesquisa documental e entrevistas semi-estruturadas.

Sobre a pesquisa documental, o foco principal foi encontrar reportagens em jornais que foram publicadas sobre o tema, na tentativa de identificar informações transmitidas pela mídia durante o processo de surgimento das referidas legislações e sobre os mesmo. Também se buscou identificar possíveis denúncias de casos de assédio sexual e assédio moral que ganharam visibilidade na mídia e assim puderam influir de alguma maneira na história do nascimento da Lei 10.224/01 e projeto de Lei 2.369/03.

Essas reportagens foram buscadas na Internet, por ser o meio eletrônico mais prático e permitir uma busca mais rápida, tendo em vista, a pouca disponibilidade de tempo que a pesquisadora tinha para coletar os seus dados. As reportagens analisadas foram obtidas do site da Secretaria de Políticas para as Mulheres, sendo que, este site foi escolhido por reunir em seu domínio muitas reportagens acerca dos dois tipos de Assédio.

Foram consultadas as leis: Constituição da República Federativa do Brasil de 1988, Consolidação das Leis Trabalhistas, Decreto-Lei no 2.848 de 1940 (Código Penal), Lei no 10.2247/01, Projeto de lei 61/99 e Projeto de lei $n^{\circ}$ 2.369/03. Além dessas referidas leis e projetos de leis foram consultadas e analisadas as notas taquigráficas de algumas sessões legislativas que foram concedidas pela Seção de Atendimento ao público do Departamento de Taquigrafia da Câmara Legislativa Federal. Estas possibilitaram uma visualização um pouco melhor do debate que se tinha entre os parlamentares acerca do tema tratado.

As entrevistas semi-estruturadas foram realizadas com 7 pessoas que acompanharam o processo de surgimento das legislações em questão. O critério de escolha foi definido na tentativa de traçar um caminho que permitisse visualizar a perspectiva do Estado, por meio da 
Secretaria de Políticas para as Mulheres (SPM), da sociedade civil, por meio da ONG Cfêmea, do Poder Legislativo, por meio da entrevista a uma pessoa que trabalham na Câmara dos Deputados e de pessoas que atuam diretamente nas causas judiciais de Assédio sexual e moral.

Foram escolhidas duas pessoas que atuam na área trabalhista, uma juíza e um advogado, pelo fato de que estes atuam diretamente com a problemática do Assédio sexual e Assédio moral. Também foi entrevistada uma pessoa da ONG Cfêmea, que é uma das ONGs mais atuantes na aprovação de leis em defesa dos direitos das mulheres, lutando nos ambientes parlamentares por mais conquistas para as mulheres.

Considerou-se importante para este trabalho entrevistar alguém da Organização Internacional do Trabalho (OIT), por ser esta uma organização que atua internacionalmente e que trata de todos os assuntos relacionados ao mundo do trabalho, sendo o Assédio sexual e moral parte desse mundo. Sendo assim, foi também entrevistada uma pessoa que trabalha na OIT.

A maioria das entrevistas foi efetuada por meio do correio eletrônico devido à falta de disponibilidade dos entrevistados em conceder entrevista pessoalmente. Sendo que, somente uma entrevista foi realizada pessoalmente.

Mesmo as entrevistas ocorrendo por meio de correio eletrônico, considerou-se importante a aplicação do termo de Consentimento Livre e Esclarecido (TCLE) que foi mandado em anexo junto com o roteiro de entrevista ao e-mail dos entrevistados. O TCLE expôs os objetivos e métodos da pesquisa, assim como, para que se destinaram as informações cedidas na entrevista. Foi utilizado um ofício de apresentação da pesquisadora para os entrevistados e instituições que assim solicitaram.

O processo de ida a campo para coletar dados trouxe à tona várias elucidações importantes em relação ao tema tratado e em relação à própria dificuldade que um pesquisador (a) enfrenta em seu dia-a-dia com o seu trabalho de coleta de dados.

Inicialmente buscou-se aplicar uma estratégia de coleta de dados equivalente a que já tinha sido aplicada em outra pesquisa relacionada também ao surgimento de uma legislação que protege as mulheres, esta mais direcionada a violência doméstica (Lei Maria da Penha). A primeira constatação da ida a campo se refere justamente a isso, essa tentativa de utilização da mesma estratégia de coleta de dados em duas pesquisas com objetos de estudo diferentes.

Logo notou-se que esta estratégia esbarraria em vários problemas. A primeira pesquisa realizada tratou de investigar o processo de surgimento da Lei Maria da Penha (Lei 
$\left.\mathrm{n}^{\mathrm{o}}: 11.340 / 06\right)$. Para isso foram entrevistadas pessoas que participaram e/ou acompanharam o surgimento da mesma, sendo estas: uma pessoa da Secretaria de Políticas para as Mulheres (SPM), uma pessoa da Ong Cfema e a própria pessoa que deu nome a Lei $\mathrm{n}^{\mathrm{o}}$ : 11.340/06, Maria da Penha Maia Fernandes. A estratégia para esta primeira pesquisa se desenvolveu com sucesso ocorrendo uma boa coleta de dados.

Devido a esse sucesso obtido buscou-se aplicar a mesma estratégia de coleta de dados na pesquisa em questão, sobre o surgimento da Lei $\mathrm{n}^{\mathrm{o}}$ : 10.224/01 e projeto de Lei $\mathrm{n}^{\mathrm{o}}$ : 2.369/03, que disciplina respectivamente o Assédio Sexual e o Assédio Moral. Contudo localiza-se aí o primeiro problema, encontrar pessoas que tenham acompanhado e/ou vivenciado o processo de surgimento da referida Lei e projeto de Lei.

No caso da primeira pesquisa, sobre o surgimento da Lei Maria da Penha, a estratégia de coleta de dados se deu com um considerável sucesso devido à peculiaridade de surgimento da mesma. O surgimento da Lei Maria da Penha se deu numa situação atípica, onde houve a participação e o acompanhamento de vários atores políticos, inclusive de âmbito internacional. Houve um caso que ganhou notoriedade na mídia, que acabou por simbolizar todos os casos de violência doméstica ocorridos no país, o caso da Maria da Penha Maia Fernandes.

Devido à denúncia na mídia desse caso, à união das Ongs feministas, à atuação em conjunto do poder executivo por meio da Secretaria de Políticas para as Mulheres (SPM) e devido a uma obrigação internacional da Comissão Interamericana de Direitos Humanos da Organização dos Estados Americanos (OEA) surgiu a Lei Maria da Penha. Esta lei nasceu por causa da união de vários atores na luta contra violência doméstica que atinge muitas brasileiras em todo o país.

A estratégia de coleta de dados adotada naquela ocasião era perfeitamente cabível e passível de ser aplicada sem muitas dificuldades. O mesmo não ocorreu com as legislações que são objeto dessa pesquisa. Como essas leis não ganharam a notoriedade na mídia que ganhou a Lei Maria da Penha, encontrar sujeitos que tenham participado e/ou acompanhado o processo de surgimento da Lei de $n^{\circ}$ : 10.224/01 e projeto de Lei 2.369/03 demonstrou ser o primeiro problema.

A primeira resposta positiva recebida em relação a entrevista foi da Ong Cfemea. Como já havia um contato, devido o trabalho anterior, não foi muito difícil conseguir uma entrevista, sendo assim, a primeira pessoa que aceitou conversar sobre o tema foi a assessora técnica e parlamentar das áreas de poder/política e trabalho/previdência, Fernanda Nunes 
Feitosa Barros. Sendo uma interlocutora-chave para o desenvolvimento ulterior da pesquisa, a assessora fez sugestões importantes sobre fontes de dados e sugeriu o próprio processo legislativo como relevante fonte de pesquisa.

Buscou-se um contato com a Secretaria de Políticas para as Mulheres (SPM), que indicou a necessidade de entrevistar a juíza trabalhista Comba Marques, colaboradora da Secretaria em várias oportunidades. O contato com a Dra Comba Marques se deu por meio de correio eletrônico, devido ao fato de que esta reside na cidade do Rio de Janeiro. A Dra Comba Marques aceitou prontamente participar desta pesquisa, sendo que, a entrevista realizou-se por meio de correio eletrônico devidos aos motivos já citados acima.

A segunda entrevista realizada ocorreu com o Sr Wolnei Tadeu Ferreira, advogado especializado na área trabalhista. O contato inicial com o Sr Ferreira aconteceu por meio de uma palestra organizada pelo Centro de Integração Empresa Escola (CIEE), na qual estava presente o Sr Ferreira ministrando a palestra. Ao final desta palestra houve uma breve conversa entre a pesquisadora e o palestrante e uma troca de e-mails, o que possibilitou uma comunicação posterior e a efetivação da entrevista. Como ocorreu com a primeira entrevista, esta segunda se realizou por meio de correio eletrônico devido ao fato de que o entrevistado reside em outro estado (São Paulo).

$\mathrm{Na}$ terceira entrevista buscou-se novamente contato com a Ong Cfemea, no caso alguma assessora que tivesse efetivamente acompanhado o processo de surgimento das referidas legislações. Foi indicado então a assessora parlamentar e integrante do colegiado, Natalia Mori Cruz. O contato se deu por meio de correio eletrônico por falta de disponibilidade para o encontro pessoal, e assim também ocorreu com a entrevista, que foi realizada com êxito

A quarta entrevista realizou-se com a Sra Márcia Vasconcelos, coordenadora do Programa de Promoção da igualdade de Gênero e Raça no Mundo do Trabalho do escritório da Organização Internacional do Trabalho (OIT) no Brasil. O contato inicial ocorreu no escritório da OIT em Brasília, onde a entrevistada trabalha, e os contatos posteriores se deram por meio de correio eletrônico, sendo que, a entrevista aconteceu pessoalmente.

O próximo passo foi buscar um contato com a divisão de saúde do trabalhador do Ministério da Saúde pelo fato de que se tinha conhecimento de um protocolo de denúncia sobre assédio moral neste local. No decorrer desta procura descobriu-se que a pessoa responsável pela condução deste protocolo não se encontrava mais trabalhando no Ministério da Saúde, sendo assim, que a tarefa não tinha sido acolhida por outro funcionário do 
Ministério, e sendo assim, não foi possível entrevistar ninguém que representasse o Ministério da Saúde.

A busca por dados estatísticos nos órgãos que têm competência para tratar do assunto em Brasília foi exaustiva e pouco produtiva. Procurou-se inicialmente colher dados na Superintendência Regional do Trabalho que localiza-se na SEPN 509 Bloco E, Asa norte. Foi informado que os casos de Assédio Sexual não são tratados por essa Superintendência e sim pela justiça criminal e que atualmente não há um controle de quantas denúncias de Assédio Moral a Superintendência Regional do Trabalho recebe. Frisou que há relatórios antigos sobre esse quantitativo de denúncias, mas que estão muito desatualizados e que possuem um acesso muito difícil e burocrático.

Foi ressaltado que a Superintendência Regional do Trabalho (SRT) não tem o poder do judiciário e por isso não há muitas medidas que podem ser tomadas por ela. As medidas tomadas são mais direcionadas a orientação e conciliação. É realizada uma conversa com ambas as partes e o empregador é chamado a assinar um termo de compromisso se comprometendo a não mais permitir que o assédio moral aconteça na sua empresa. Percebeuse que não há um trabalho de acompanhamento das vítimas posterior a essa fase do acordo e que não há como saber ao certo o quão eficaz tem sido essa intervenção da SRT. Em caso de persistência do assédio moral o caso é encaminhado ao Ministério Público.

Questionou-se a respeito do Núcleo de Apoio e Diversidade nas Relações de Emprego que existia na SRT e foi informado que o mesmo não existe mais já há algum tempo. Para saber por que havia acontecido esse fato com o Núcleo de Apoio e Diversidade nas Relações de Emprego o foi aconselhado procurar o Ministério do Trabalho e Emprego (MTE), pois, é o MTE quem elabora os regimentos utilizados pela SRT. Assim, após a visita à SRT partiu-se para o contato e busca de dados com o MTE. Foi informado que o MTE não faz um registro das queixas que recebe de assédio sexual e moral, somente faz um encaminhamento para os devidos órgãos que tratam desse tema. Por isso, não há uma estatística das denúncias recebidas. Foi aconselhado procurar novamente a SRT, pois, que não haveria possibilidade de o MTE contribuir para com esse trabalho e que seria mais produtivo procurar a justiça trabalhista e o Ministério Público do Trabalho (MPT).

Ao procurar a justiça do trabalho os resultados também não foram muito positivos. No Tribunal Regional do Trabalho (TRT) foi informado que essas ações de assédio moral e sexual não são tratadas pelo TRT e sim pela justiça comum. Buscou-se então o Fórum Des. Milton Sebastião Barbosa para tentar mais uma vez fazer o levantamento de um quantitativo 
de denúncias de assédio sexual e assédio moral que ocorreu nos últimos anos ou que ocorre a cada ano. A pessoa responsável pelo atendimento no setor de distribuição de processos do Fórum Des. Milton Sebastião Barbosa, informou que não havia a possibilidade de fazer esse tipo de busca no sistema. Foi relatado que o sistema não faz um registro estatístico separando as ações por especificidade de crime. Então, poderia haver um levantamento de todas as ações judiciais que ocorreram ou que ocorrem em qualquer período solicitado, mas não há uma separação dessas ações, não é possível saber dessas ações quantas são de assédio sexual e moral e quantas são de outros crimes.

O Ministério Público do Trabalho foi o único órgão procurado que forneceu alguma informação para este trabalho. O sistema de gerenciamento de dados do MPT estava em mudança e não havia possibilidade de buscar dados antigos por ele. Por isso os poucos dados coletados neste local são do ano de 2009/2010.

Durante todo esse período de coleta de dados buscou-se contato com os parlamentares que proporam a referida Lei e projeto de Lei, sem muito sucesso.

É necessário ressaltar a importante contribuição da orientadora desta pesquisa, a professora Doutora Silvia Yannoulas, que não somente forneceu bons direcionamentos para este estudo, como também, acionou os seus contatos e conseguiu novas entrevistas para este trabalho. Por meio do contato feito pela professora, foi possível realizar uma entrevista com a Deputada Rita de Cássia Paste Camata. Esta entrevista aconteceu com sucesso, por meio de correio eletrônico, como as outras anteriormente realizadas.

Outro contato importante que foi obtido por meio da ajuda da professora foi o da Corregedora-Geral do Ministério Público Federal (MPF), Professora Doutora Ela Wiecko Volkmer de Castilho. Foram feitos contatos por meio de correio eletrônico e assim foi feita com êxito mais esta entrevista. A participação da Sra Corregedora-Geral do MPF foi extremamente importante, tendo em vista que, a mesma não forneceu somente a entrevista, mas também, forneceu material para estudo e para maior conhecimento a respeito do tema.

A última entrevista foi realizada a partir dos contatos da professora foi com a integrante da Ong SOS Corpo Instituto Feminista para a Democracia, a Sra. Verônica Ferreira. Esta entrevista também se realizou por meio de correio eletrônico, pois a Sra. Verônica reside em Recife.

Percebe-se com a ida a campo foi uma verdadeira saga. As dificuldades para encontrar entrevistados e dados demonstram que o tema ainda não está enraizado na sociedade brasileira e nem forma parte importante da agenda política em discussão. 


\title{
Capítulo II. RELAÇÕES DE GÊNERO E DIVISÃO SEXUAL DO TRABALHO: O CONTEXTO DOS ASSÉDIOS
}

\author{
Divisão sexual do Trabalho
}

A reflexão sobre as mulheres no mercado de trabalho está intrinsecamente ligada à discussão de gênero e da divisão sexual do trabalho, como diz Carloto:

\begin{abstract}
A existência de gêneros é a manifestação de uma desigual distribuição de responsabilidade na produção social da existência. Do lugar que é atribuído socialmente cada um, dependerá a forma como se terá acesso à própria sobrevivência como sexo, classe e raça, seno que esta relação com a realidade comporta uma visão particular da mesma. (CARLOTO, 2007, p.202)
\end{abstract}

Hirata e Kergoat (2007) utilizam-se de dois conceitos de conteúdos diferenciados para abordar a questão da divisão sexual do trabalho. Uma questão que se prende mais as distribuições desiguais de tarefas entre homens e mulheres no mercado de trabalho e suas variações, associando a esse ponto a desigual divisão do trabalho doméstico entre os homens e as mulheres, e a outra, que complementa a primeira, e que considera que essa desigualdade é sistemática, provando que a sociedade utiliza desses processos de diferenciação para hierarquizar as atividades e os sexos, criando assim o que se chama de gênero.

Segunda as autoras (2007), a idéia inicial que fez surgir à discussão do tema da divisão sexual do trabalho era na verdade refletir sobre o tema trabalho. O ponto de partida dessa discussão era o pensamento de que trabalho doméstico também era trabalho e por isso deveria ser incluído nessa categoria. Sendo assim, na França, nos anos de 1970, surgiram uma série de trabalhos, impulsionados pelo movimento feminista, que serviriam de base para a construção teórica do desse conceito. Inicialmente isso ocorreu dentro da Etnologia, depois da Sociologia e da História.

De acordo com as autoras em questão, conceito teria surgido quando as mulheres perceberam que também realizavam trabalho, mas que ao contrário do que acontecia aos homens, esse trabalho não era pago, o trabalho doméstico. Tinha-se como desculpa que as mulheres tinham atributos naturais para aquele ofício e por isso o que elas faziam não era considerado trabalho. A partir dessa visão de que as atividades feitas em casa era trabalho, nasce à noção de divisão sexual de trabalho.

Hirata e Kergoat (2007) explicam que no começo a divisão sexual do trabalho tinha a intenção de articular duas esferas, contudo, essa noção se mostrou precária e levou a uma 
reflexão sobre a relação social entre o grupo dos homens e das mulheres. Isso as francesas nomearam de relações sociais de sexo.

Todo esse movimento, de acordo com as autoras (2007), levou muitos países a repensar o trabalho e suas categorias, fazendo uso da abordagem da divisão sexual do trabalho. Como consequiência houve um questionamento radical da sociologia da família e do paradigma funcionalista que embasava a mesma.

Depois de toda essa trajetória, Hirata e Kergoat (2007) chegam ao conceito mais divulgado atualmente de divisão sexual do trabalho:

\begin{abstract}
A divisão sexual do trabalho é a forma de divisão do trabalho social decorrente das relações sociais entre os sexos; mais que isso, é um fator prioritário para a sobrevivência da relação social entre os sexos. Essa forma é modulada histórica e socialmente. Tem como características a designação prioritária dos homens à esfera produtiva e das mulheres à esfera reprodutiva e, simultaneamente, a apropriação pelos homens das funções com maior valor social adicionado... (HIRATA e KERGOAT, 2007, P.599)
\end{abstract}

Esse conceito é o mais conhecido e mais acordado, mas não é por si só suficiente para caracterizar a divisão sexual do trabalho, de acordo com as autoras em questão. Para Hirata e Kergoat (2007), o conceito de divisão sexual do trabalho envolve ainda dois princípios, o da separação e o da hierarquia, esses que são legitimados por meio da ideologia naturalista, a qual reduz o gênero ao sexo biológico.

Os princípios da separação e da hierarquia são aceitos por todas as sociedades, o que não significa que o conceito em si de divisão sexual do trabalho seja imutável, muito pelo contrário, pelo que afirmam as autoras, a divisão sexual não é estável, mas, a distância entre os dois grupos sim.

Nesse sentido, afirma Carloto (2007) que a divisão sexual do trabalho assume formas que conservam as tradições nas quais há modalidade de trabalho feminino e modalidade de trabalho masculino e as desigualdades nessa relação ultrapassam a divisão das atividades, mas chegam a tipificar os critérios de qualificação das tarefas, os salários e até a disciplina no trabalho. Essa divisão sexual do trabalho enraizada nessa sociedade mantém a discriminação em todos os âmbitos da vida das mulheres, principalmente, no trabalho.

Nesse contexto de mudanças, de novas configurações da divisão sexual do trabalho, Hirata e Kergoat (2007) falam sobre dois pontos que têm marcado esta época. O primeiro ponto é que a divisão sexual do trabalho se ajusta as formas de trabalho e de emprego e que a flexibilização pode enraizar mais as formas estereotipadas das relações sociais de sexo. 
De acordo com o IPEA (Instituto de Pesquisa Econômica Aplicada, 1997), no texto para discussão 473: Modernização produtiva e relações de trabalho: perspectivas e políticas públicas, flexibilização do trabalho, ou especialização flexível consiste num novo paradigma produtivo que possui três grandes características: a primeira se refere às inovações tecnológicas trazidas pela informática, que permitiram um grande aumento da produtividade e uma maior flexibilidade dos processos produtivos; a segunda diz respeito a mudanças nas relações entre as empresas, que passam a praticar mais a terceirização, desmembrando parte de suas atividades e adquirindo serviços e insumos de outras empresas, e aderem a uma tendência de descentralização empresarial e desverticalização industrial; a terceira relacionase ao surgimento de novos processos organizacionais na produção e no trabalho no interior das empresas que pretendem o aumento da eficiência.

O segundo ponto refere-se a uma parcela de mulheres que possuem interesses que vão de encontro aos interesses de outras mulheres, essas outras são mulheres que foram atingidas mais fortemente pelo emprego precário em geral. O trabalho precário decorre em grande parte das transformações pelas quais o mundo do trabalho vem passando com o processo de especialização flexível. De acordo como o IPEA (1997), emprego precário refere-se à relação de trabalho que ocorre por meio de um processo de contratação situado à margem de vários direitos trabalhistas e quase sempre com salário menores. Essa questão da precarização da mão-de-obra feminina será abordada mais detalhadamente no tópico seguinte.

No intuito de sintetizar as novas modalidades da divisão sexual do trabalho, Hirata e Kergoat (2007) destacam dois pontos principais: o primeiro refere-se a uma reorganização do trabalho no âmbito assalariado e no âmbito doméstico, o que causa uma externalização e uma nova divisão do trabalho doméstico.

O segundo remete a um duplo movimento: de aparente diminuição das tensões nos casais mais de maior poder aquisitivo e de aumento no número de mulheres em trabalhos de nível superior ao mesmo tempo em que há também aumento no número de mulheres trabalhando em situação precária.

Em relação a esse primeiro movimento exposto no parágrafo anterior, Araújo e Scalon (2005) explicam que apesar dessa aparente diminuição de tensão, o acesso das mulheres no mercado de trabalho ainda permanece ligado a uma adequação do mesmo a suas relações familiares, como se fosse uma parte externa das suas vidas. Já em relação ao sexo masculino, o trabalho continua naturalizado, considerado como um imperativo. 
Araújo e Scalon (2005) afirmam que mesmo ocorrendo uma leve mudança nos padrões culturais, nas visões de homens e mulheres em direção a uma cultura mais igualitária, o padrão de divisão sexual do trabalho doméstico permanece praticamente inerte.

Sendo assim, Araújo e Scalon (2005) expõem que apesar de algumas poucas variações, o trabalho conceituado como reprodutivo ou doméstico é visto como feminino e o trabalho defendido como produtivo ou remunerado é visto como masculino e por isso, por suas respectivas vantagens e desvantagens, tem sido atribuído grande parte das razões para a permanência dos homens em cargos importantes da hierarquia.

Ainda nesse contexto de as novas configurações da divisão sexual do trabalho, Hirata (2002) escreve sobre essa temática na indústria e em relação as novas tecnologias. A autora afirma que na indústria, geralmente, as mulheres são empregadas somente para os trabalhos de escritório e em pequenas proporções nos laboratórios de controle de qualidade. Enfatiza que "O número de trabalhadoras nesses ramos, de alto desenvolvimento capitalista e forte modernização tecnológica, raramente ultrapassa 5\%. (HIRATA, 2002, P.205)

Mesmo no trabalho no escritório onde as mulheres são normalmente mais empregadas, com a introdução de novas tecnologias, a autora (2002) afirma que houve mudanças, a divisão sexual do trabalho entre homens e mulheres teria aumentado. Isso devido à informatização do trabalho no escritório que teria reforçado a divisão existente entre trabalho qualificado e nãoqualificado, entre as tarefas de direção e a de execução.

De acordo com Hirata (2002), nas indústrias de processo contínuo as novas tecnologias não mudaram a divisão sexual do trabalho, permanecendo a distância entre os homens e as mulheres a mesma. O mesmo não se pode dizer da indústria têxtil, pois, com a introdução de novas tecnologias aconteceu a saída maciça das mulheres e com o surgimento de novas qualificações a entrada em grande escala dos homens. Isso indicaria uma mudança na divisão sexual do trabalho porque haveria uma polarização entre postos desqualificados femininos e qualificados masculinos.

De uma maneira geral, Hirata (2002) acredita que as relações sociais entre homens e mulheres no âmbito externo ao trabalho estruturam a divisão sexual do trabalho profissional. A autora acredita que há um certo controle masculino dos instrumentos de produção e que isso direcionaria as mulheres para as ocupações mais simples.

Em relação a tecnologia, a autora defende que as mudanças não têm o mesmo impacto sobre as mulheres e sobre os homens, nem que tem o mesmo impacto entre as mulheres e o 
homens de países desenvolvidos e não desenvolvidos, nem que tem o mesmo impacto sobre diferentes categorias de mão-de-obra.

Hirata (2002) acredita que a divisão sexual do trabalho não evoluiu no mesmo ritmo da história da tecnologia, apenas deslocou as fronteiras do feminino e do masculino, dando a impressão de que jamais haverá o fim da divisão sexual. As novas relações sociais tendem a continuar reproduzindo a idéia de que as qualificações femininas são um talento natural.

As barreiras enfrentadas pelas mulheres no mercado de trabalho

Nos últimos anos houve uma entrada maciça das mulheres no mercado de trabalho. No Brasil, a participação feminina em 1979 representava uma porcentagem de $31,7 \%^{2}$ da População Economicamente Ativa (PEA), já em 1999 essa porcentagem aumentou para 41,4\% da PEA. Dados mais recentes da PNAD (Pesquisa Nacional por Amostra de Domicílios) mostram que esse número cresceu para 47,2\% no ano de 2008. Esta mesma pesquisa revela que o número de mulheres que trabalham com carteira assinada também aumentou e representa um total de $33,58 \%$ no ano de $2008^{3}$. Muitos são os fatores que contribuíram para esse aumento do número de mulheres no mundo do trabalho remunerado ${ }^{4}$.

Contudo, esse crescimento da participação feminina no mercado de trabalho tem sido acompanhado por muitas práticas de discriminação que se tornam verdadeiras barreiras para a entrada e permanência das mulheres no mundo do trabalho. Na cartilha Comunicados do IPEA "Instituto de Pesquisa Econômica Aplicada" (2010), afirma-se que a inserção das mulheres no mercado de trabalho tende a ser mais precarizada e não vem acompanhada de uma "desobrigação" das mesmas no que se refere aos afazeres domésticos.

Nesta cartilha, (IPEA, 2010) é exposto que as leis, as políticas e os serviços públicos se organizam de uma maneira a priorizar um modelo de família que não condiz com a realidade atual, um modelo tradicional de família, o qual o homem é único provedor e a

\footnotetext{
${ }^{2}$ ARROIO, Ana e RÉGIGNIER, Karla. O Novo Mundo do Trabalho: Oportunidades e Desafios para o Presente. Disponível em: http://www.senac.br/BTS/272/boltec272d.htm . Acesso em 10 de agosto de 2010.

${ }^{3}$ Dados retirados da página: http://www.observatoriodegenero.gov.br/menu/noticias/destaques-da-pnad2008. Acesso dia 12 de setembro de 2010.

${ }^{4}$ Afirma-se que houve um aumento do número de mulheres no mundo do trabalho remunerado por se considerar neste trabalho que as mulheres já se encontravam no mundo do trabalho, contudo, um trabalho não remunerado, o trabalho doméstico.
} 
mulher é a figura responsável pelos cuidados domésticos. Desta forma se reforça cada vez mais a naturalização da obrigação feminina pelos afazeres domésticos e isso exerce especial influência na hora da busca por emprego da população feminina.

As dificuldades para as mulheres conseguirem um emprego são nitidamente maiores que para os homens, e isso não ocorre somente pelo fato de que as mulheres na hora de procurar um emprego buscam encontrar algo que dê para conciliar com as tarefas de casa. Isso decorre de várias outras razões que se relacionam diretamente ao imaginário cultural do papel das mulheres na sociedade.

Yannoulas (2003) explica que esse fenômeno da diferente inserção de homens e mulheres no mercado de trabalho chama-se segmentação ou segregação dos mercados de trabalho baseada no gênero. Diante disso, a segmentação relatada pela autora remete a uma focalização das chances de trabalho para o público feminino em setores específicos e com números de vagas normalmente mais reduzidos.

De acordo com Yannoulas (2003), a força de trabalho feminina enfrenta também uma divisão sexual horizontal do mercado de trabalho, a qual as mulheres acabam se concentrando em um determinado setor, isso devido às tradicionais características atribuídas culturalmente as mulheres. Essas funções geralmente se enquadram dentro de um contexto de atividades que se originam das funções de reprodução social e cultural, as quais até hoje são atribuídas quase exclusivamente às mulheres.

A autora em questão também situa outra problemática que dificulta a vidas das mulheres no mercado de trabalho, a divisão sexual vertical do trabalho. De acordo com Yannoulas (2003), essa divisão se refere ao fato de que as mulheres como grupo já se encontram, na corrida para um emprego, em situação desfavorável em relação aos homens. Isso em se tratando de vários aspectos relacionados ao trabalho, como: "salário, ascensão funcional (cargos), e condições de trabalho (em função de ser o homem o responsável pelo sustento familiar)" (YANNOULAS, 2003, P.48)

Outro ponto interessante de se lembrar é o fato de que as mulheres, de acordo com Yannoulas (2003), enfrentam uma seleção na hora de procurar empregos que é discriminatória até dentro do próprio grupo de mulheres. Preferem-se as mais jovens, mais escolarizadas, as que não têm marido.

A discriminação que as mulheres enfrentem no mercado de trabalho podem ser dividas em três formas, de acordo com Yannoulas (2003): direta, indireta e autodiscriminação. Primeira discriminação refere-se a uma discriminação que se dá nas regras, códigos, com 
recomendações expressas de exclusão de um determinado grupo. Essa discriminação não ocorre atualmente devido ao forte sentimento de busca que se tem hoje em dia pela "igualdade".

A segunda forma de discriminação é uma "burlação" da primeira forma que não pode continuar existindo. Essa forma se refere a práticas admitidas informalmente que criam desigualdades entre pessoas por causa da raça, ou do gênero, ou da religião. O terceiro tipo de discriminação é uma espécie que atua mais no inconsciente das mulheres, é uma vigilância das suas próprias ações decorrente dos parâmetros estabelecidos pela manifestação da discriminação indireta. (Yannoulas, 2003)

Yannoulas (2003) afirma que as consequiências de toda essa discriminação influem diretamente na escolha das mulheres de profissões menos prestigiadas e que detém um salário mais baixo. A autora também elenca um conjunto de outras consequiências que advêm dessas discriminações e que são importantes de serem citadas:

\footnotetext{
...impedimentos ao acesso e promoção no emprego, salários inferiores, dificuldade para ascensão profissional em razão de responsabilidades familiares, dificuldade para admissão ou causa de demissão com base na maternidade (solicitação de certificado de esterilização ou de não estar grávida para admissão na empresa, apesar da proibição legal expressa), assédio sexual, entre outras. (YANNOULAS, 2003, P. 52)
}

Devido a esses fatores de discriminação que recaem sobre as mulheres no mercado de trabalho decorre também um alto índice de desemprego. De acordo com Yannoulas (2003), as taxas de desemprego entre as mulheres são maiores que entre os homens. O subemprego e a ocupação informal também atingem maciçamente as trabalhadoras.

A distância salarial também tem sido bem debatida, justamente por persistir quase inalterável nos últimos anos. Yannoulas cita que em 1999 os homens brasileiros recebiam uma média de 3,2 salários mínimos e as mulheres, nem atingiam a média de 1,5 salário mínimo.

O mais incrível é que, de acordo com Yannoulas (2003), a maior parte dessa diferença de salários se relaciona a discriminação que as mulheres sofrem, não a capacidade produtiva da mão-de-obra feminina, pois as mesmas têm apresentado níveis de escolaridade maiores que os homens, assim, subentende-se que elas teriam maior rendimento ou produtividade.

Há também a possibilidade de ter acontecido um deslocamento na discriminação do número de anos de escolaridade para o tipo de escolaridade, tendo em vista que os empregos que as mulheres se especializam e os cargos que as mesmas ocupam são considerados femininos e são os que ganham menos. Há que se considerar que todas essas dificuldades 
aumentam quando se entra no assunto da raça. As mulheres negras sofrem um tipo de exclusão mais aguda. (Yannoulas, 2003)

O crescimento das mulheres no mercado de trabalho em relação à população economicamente ativa não ocorreu somente no Brasil, Nogueira (2004) afirma que na União Européia esse crescimento também foi significativo. Mesmo durante a crise de emprego que ocorreu nos anos 80, a taxa de crescimento da atividade feminina continuou a crescer. (MARUANI apud NOGUEIRA, 2004)

De acordo com Maruani (MARUANI apud NOGUEIRA, 2004) esse crescimento se deu de maneira sustentada, o qual ele exemplifica com os seguintes dados:

...enquanto em 1962 a França contabilizava 6,6 milhões de mulheres e 13,2 milhões de homens em atividade, em 1998, esse números chegaram a 11,7 milhões de mulheres e 14,1 milhões de homens. Podemos notar que no espaço de três décadas houve um ingresso de mais de 5 milhões de mulheres a 1 milhão de homens no mercado de trabalho daquele país, apesar da crise os emprego que se abateu durante esse período. (MARUANI apud NOGUEIRA, 2004, P.45)

Outro ponto que se assemelha ao Brasil é no que se refere aos salários, ou melhor dizendo, as diferenças salariais entre homens e mulheres. Nogueira (2004) aponta que a desigualdade é bastante significativa no momento em que se compara a porcentagem de homens e mulheres relacionando com os baixos salários recebidos na União Européia. A configuração atual da divisão sexual do trabalho insiste em manter a segmentação e a remuneração diferenciada entre a população masculina e a feminina.

A autora em questão pontua que junto com essa crescente feminização do mundo do trabalho vem também uma crescente desvalorização do trabalho das mulheres e esses fatores têm caracterizado a divisão sexual do trabalho nos países de capitalismo avançado. Nogueira (2004) afirma que a maioria dos postos de trabalho que estão sendo criados, os quais pagam salários mais baixos, estão sendo ocupados pelas mulheres e esses salários mais baixos estão relacionados a empregos em tempo parcial.

Essa percepção refere-se ao fato das mulheres ainda aceitarem como atividade principal de suas vidas aquelas relacionadas ao cuidado com o lar, levando dessa maneira a procura por empregos que permitam a conciliação do trabalho remunerado com o trabalho doméstico, que ainda é exercido quase exclusivamente pelas mulheres.

De acordo com Nogueira (2004), essa busca por conciliação fez com que as mulheres entrassem de cabeça nos postos de trabalho em tempo parcial e não somente isso, mas também que aderissem ao emprego temporário. O resultado disso é somente a duplicação de precariedade nas condições do trabalho. 
Ainda é observado por Nogueira (2004) a questão do subemprego e do desemprego, que se mostram também presentes de maneira mais forte entre a população feminina, apesar de marcar a classe trabalhadora de uma forma geral.

De uma maneira geral é perceptível que as conseqüências da divisão sexual do trabalho persistem na sociedade, tornando a vida das mulheres cada vez mais difícil no mercado de trabalho.

As mudanças que ocorreram no mundo do trabalho contribuíram para ampliar a participação feminina no mercado de trabalho, mas ao mesmo tempo reforçando as desigualdades que já existiam entre a população feminina e a masculina. Como diz Yannoulas (2003), é necessário uma intervenção do Estado para que alguma mudança realmente ocorra em favor das mulheres: “... as relações de gênero igualitárias no mundo do trabalho devem ser fomentadas especificamente pelas políticas públicas, pois os mercados não conseguem regular espontaneamente esse tipo de desigualdade...”(YANNOULAS, 2003, P. 62) 


\section{Capítulo III. ASSÉDIO SEXUAL}

\section{Contextualizando e Definindo o Assédio Sexual}

Apesar de o fenômeno ser considerado antigo, o debate acerca desse tema data da década de 70, com as feministas norte-americanas da Universidade Cornell. Atribui-se a elas a criação de uma expressão que versava sobre a conduta de um superior hierárquico sobre seu funcionário com o interesse sexual, chegando-se assim a expressão assédio sexual (sexual harassment - Moreira, 2002).

O problema do assédio sexual não pode ser considerado individualmente, mas deve necessariamente remeter ao campo social, como diz Souza:

As causas do assédio sexual, bem como as da violência de gênero, tema maior no qual o assédio está incluído, são sociais e encontram suas raízes numa gramática de gênero que torna cada um e todos os homens potencialmente violentos. Gramática de gênero significando legalidades e regularidades que constroem e perpassam o tecido social, bem como constroem subjetividades gendradas. (SOUZA, 2006.p. 04)

Esta problemática que degrada o ambiente de trabalho é considerada por muitos autores uma das formas mais antigas de violência contra mulher e que encontra a sua gênese no patriarcalismo, machismo e sexismo presente na sociedade.

De acordo com Souza (2006), o assédio sexual tem suas raízes no patriarcado, que é anterior a sociedade capitalista, e se tornou mais intenso no período pós- Segunda Guerra Mundial, quando houve uma entrada maciça das mulheres no mercado de trabalho. Segundo a autora, o assédio sexual se manifesta na forma das relações patriarcais, na qual o corpo das mulheres e sua sexualidade não pertencem a elas, e sim aos homens. Havendo recusa, eles passam pra vingança.

Segundo Costa, estima-se que o patriarcado tenha surgido por volta do quarto milênio antes da era cristã na Mesopotâmia. (COSTA, 1995, p.30) Segundo a autora, o nascimento do patriarcado se relaciona a tentativa dos homens de dominar a capacidade de reprodução das mulheres quando estes teriam percebido que o papel masculino na reprodução era condicionado às vontades femininas. Sendo assim, para assegurar suas hereditariedades, os homens começaram a criar meios de controlar a sexualidade das mulheres. A principal forma que os homens encontraram para submeter às mulheres a eles foi por meio da coerção física e econômica. 
Percebe-se que o assédio sexual é um tipo de violência que se sustenta, em diversos aspectos, pela própria cultura. Moreira (2002) afirma que a nossa cultura mantém um padrão de sexualidade, no qual as mulheres devem conter a sua sexualidade e os homens possuem uma necessidade de variedade sexual.

Devido a esse patriarcalismo e machismo que marcam a sociedade ocorre com freqüência o fenômeno da culpabilização da vítima também nas relações trabalhistas, tem-se uma resistência de perceber esse problema como social, freqüentemente fazendo com que a responsável pelo assédio seja a própria vítima.

Como afirma Costa (1995), a convicção de que as mulheres são responsáveis pelas atitudes masculinas tem servido de base para a impunidade dos homens que praticam diversas formas de violência contras as mulheres, dentre elas o assédio sexual.

Como diz Freitas (2001) o aspecto mais latente da situação do assédio é a relação entre desiguais, não se referindo somente entre o feminino e o masculino, mas principalmente entre a capacidade que um dispõe de penalizar o outro.

Bosco (2001) acrescenta que o ambiente de trabalho é favorável ao assédio sexual por ser um espaço onde há uma forte presença das relações de hierarquia e por haver uma tendência a acontecer o assédio justamente nesses espaços.

Não obstante ao fato de que as maiores vítimas do assédio sexual são as mulheres, é importante mencionar que os homens também são vítimas dessa problemática, contudo, em proporção bem menos significativa que as mulheres.

Sem descartar essa hipótese das mulheres serem as maiores vítimas do assédio sexual devido a uma questão cultural, Maurice Depreau apud Pamplona Filho (2006) atribui essa incidência maior sobre a população feminina a dois fatores: estratificação vertical e segregação horizontal. O primeiro refere-se ao fato de que as mulheres normalmente ocupam cargos que são subordinados a homens, e o segundo diz respeito, ao que já foi citado no capítulo anterior, a uma segregação que relaciona a ocupação das mulheres em empregos em função do sexo, em função das tradicionais características atribuídas às mesmas.

Não bastava às inúmeras dificuldades que as mulheres enfrentam no mercado de trabalho, como: menores salários que os homens, menores possibilidades de conseguirem emprego, menores chances de ascensão dentro da empresa, o segmento feminino ainda enfrenta uma triste dificuldade, que é o assédio sexual.

O assédio sexual, como já foi falado, é um problema antigo que está em discussão recentemente. Não há ainda um consenso sobre uma definição do termo, pois, alguns autores 
acreditam que é fundamental para a ocorrência do mesmo uma relação de subordinação hierárquica e outros acreditam que o poder hierárquico não constitui elemento essencial para caracterizar o assédio sexual.

Lopes (2006) é um dos autores que acreditam na essencialidade do poder hierárquico para a configuração do assédio sexual. Sendo assim, a autora define assédio sexual como: "toda tentativa por parte do empregador ou de quem detenha poder hierárquico sobre o empregado, a obter deste, favores sexuais através de conduta indesejada e rejeitadas, com o uso do poder que tem nas mãos e de ameaças com relação a perde de emprego." (LOPES, 2006, P. 3)

Souza (2006) também defende a questão do poder hierárquico no assédio quando defende que o ambiente em que ocorre o assédio não é por si só condição suficiente para caracterizar o fenômeno, no caso, o que importa realmente é a relação de poder que envolve a vítima e o assediador. $\mathrm{O}$ assediador arma uma série de situações que obriguem a mulher a aceitar o assédio, quando há uma resposta negativa, o autor do assédio passa a perseguição e a punição das mais variadas formas. Sendo assim, a autora define assédio sexual como:

... alguma ameaça, perseguição ou hostilidade contra o (a) subordinado (a), após uma abordagem sexual rejeitada. Por envolver uma situação de poder, caracteriza-se a situação de assédio, no sentido de cercar, deixar sem saída. Nessas condições, a pessoa assediada teme por medo de comprometer sua sobrevivência, que na sociedade contemporânea se realiza por meio do salário percebido em troca de uma jornada de trabalho. (SOUZA, 2006, P. 03)

Souza (2006) ressalta ainda que o assédio sexual pode, em determinadas circunstâncias, dá origem ao assédio moral. Apresentando-se inicialmente o assédio sexual, e acontecendo a recusa, o assediador pode se utilizar do sentimento de vingança e partir para a retaliação, fazendo uso de atitudes que caracterizam o assédio moral. Mas a autora frisa que não se pode afirmar que todo o assédio moral foi precedido de um assédio sexual.

Lippmann (2001) é outro autor que defende firmemente que para se configurar assédio sexual é necessário o poder hierárquico,

... o assédio se caracteriza através dos pedidos de favores sexuais realizado pelo superior hierárquico com promessa de tratamento diferenciado em caso de aceitação e, de represália ou ameaças em caso de recusa.[...] Resta evidenciado, portanto, o poder que o sujeito ativo detém de influenciar na carreira do sujeito passivo. Essa influência é considerada pela doutrina pátria fundamental para a caracterização do assédio sexual, que pode se caracterizar através da ameaça de dispensa, transferência, perda de oportunidades de promoção ou, até mesmo, através de promessas de favorecimento e em caso de aceitação da proposta sexual. (LIPPMAN, 2001, P. 16) 
Moreira (2002) também relata sobre a importância do poder hierárquico ao considerar que para se caracterizar o assédio sexual não é preciso haver ameaças ou promessas verbais, a situação de poder que possui o superior hierárquico em relação a uma subalterna promovendo atitudes indesejáveis, por si só, já configura uma ameaça, mesmo que não verbal.

Contudo há autores que não consideram o poder hierárquico como fundamental na situação de assédio, um deles é Pamplona Filho (2006) que denomina o poder hierárquico como um elemento acidental na situação de assédio. $\mathrm{O}$ autor acredita que o problema do assédio sexual precisa ser encarado como um problema de discriminação e de cerceio da liberdade sexual, e não simplesmente como um mero assunto de abuso de poder.

Pamplona Filho (2006) elenca como elementos caracterizadores do assédio: sujeitos, agente (assediador) e destinatário (assediado); conduta de natureza sexual; rejeição à conduta do agente e reiteração da conduta. O autor admite que sua visão da problemática se diferencia da visão da maioria dos autores, contudo, o mesmo não demonstra se incomodar com tal fato.

Pamplona Filho defende então o assédio sexual como "toda conduta de natureza sexual não desejada que, embora repelida pelo destinatário, é continuadamente reiterada, cerceando-lhe a liberdade sexual" (PAMPLONA FILHO, 2006, P. 256)

Atualmente os autores definem que existem duas espécies de assédio sexual, o assédio sexual por chantagem e o assédio sexual por intimidação. A primeira pressupõe um poder hierárquico sobre o assediado e a segunda refere-se a uma degradação do ambiente de trabalho por meio de incitação sexual inconveniente que cria uma situação ofensiva no ambiente. Esta segunda é considerada por muitos autores como um tipo geral de assédio que não ocorre unicamente no ambiente de trabalho.

Pamplona Filho (2006) explica que o assédio sexual por chantagem é também conhecido como assédio sexual Quid Pro Quo, que significa literalmente: “isto por aquilo". Essa espécie de assédio acontece quando alguém se vale do seu poder para chantagear outro, exigindo da assediada a prática de um ato de natureza sexual, que não é desejado pela vítima, sob ameaça da perda do emprego ou de determinado benefício. Acontece também quando o assediador impõe a prática de um ato sexual ao assediado com a promessa de que o mesmo vai ganhar algum benefício, como se fosse uma troca. É necessário explicar que no ordenamento jurídico brasileiro somente esta espécie de assédio sexual é criminalizada no código penal.

De acordo com Pamplona Filho (2006), a segunda espécie de assédio sexual pode ser chamada de assédio sexual ambiental. O assédio sexual por intimidação ou assédio sexual 
ambiental consiste em um tratamento que agride o direito de uma pessoa trabalhar em um ambiente sexualmente sadio, por isso, a expressão assédio sexual ambiental.

Nesta segunda modalidade de assédio é que se faz possível visualizar a situação de assédio sem o poder hierárquico. Nessa espécie o poder é irrelevante e quem viola o direito a um ambiente de trabalho sadio normalmente é um companheiro de trabalho que possui a mesma posição hierárquica do (a) assediado (a). Como diz Pamplona (2006), esse tipo de assédio sexual é o mais amplo e possui como caracterizadores os atos:

...abuso verbal ou comentários sexistas sobre a aparência física do empregado; frases ofensivas ou de duplo sentido e alusões grosseiras, humilhantes ou embaraçosas; perguntas indiscretas sobre a vida privada do trabalhador; separá-lo dos âmbitos próprios de trabalho para maior intimidade das conversas; condutas "sexistas" generalizadas, destacando persistentemente a sexualidade em todos os contextos; insinuações sexuais inconvenientes e ofensivas, solicitação de relações íntimas, mesmo sem exigência de coito, ou outro tipo de conduta de natureza sexual, mediante promessas de benefícios ou recompensas; exibição de material pornográfico, como revistas, fotografias ou outros objetos, assim como colocar nas paredes do local de trabalho imagens de tal natureza; apalpadelas, fricções ou beliscões deliberados e ofensivos; qualquer exercício de violência física ou verbal. (PAMPLONA, 2006. P. 263)

Como já foi citado anteriormente, esse tipo de assédio não está tipificado no ordenamento jurídico brasileiro, mesmo assim, é uma forma de violação à liberdade sexual e, portanto, deve ser condenada.

Torna-se importante explicar também que o assédio sexual se difere do abuso sexual. De acordo com Pamplona Filho (2006), o assédio sexual é um cerco insistente e indesejado para a prática do ato sexual, caracteriza-se mais por ser atos preparatórios a prática sexual. A partir do momento que o ato se consuma, o fato deixa de ser caracterizado como assédio e passa a ser abuso, que possui penalizações mais graves.

\section{Legislação sobre o Assédio Sexual}

Em relação à legislação sobre assédio sexual, o legislativo brasileiro agiu um pouco atrasado se compararmos com outros países, como os Estado Unidos que criminalizaram o assédio sexual na década de 70. Mas mesmo agindo atrasado, ele agiu e isso é o que importa.

De acordo com Dai Bosco (2001) o projeto de lei $n^{\circ}: 61$ de 1999, proposto pela deputada Iara Bernardi tinha como objetivo criminalizar as práticas de assédio sexual evocando como argumento o fato de que os direitos inerentes a dignidade da pessoa humana e igualdade entre os sexos marcavam o século e para que esses direitos fossem efetivamente 
cumpridos era necessário adequações a legislação. Justificou também que essa lei seguiria uma tendência do direito internacional que buscava combater formas de violência de gênero.

Inicialmente o projeto da deputada Iara Bernardes previa em seu texto original uma série de situações passíveis de agravamento de pena, no art. $2^{\circ}$, por exemplo, previa aumento de pena em cinco situações:

...a) quando o crime fosse cometido com concurso de duas ou mais pessoas (inciso I); b) quando o agente fosse descendente, padrasto, madrasta, irmão, tutor, curador ou preceptor da vítima (inciso II); c) se o crime fosse cometido por pessoa que se prevalecesse de relações domésticas, religiosas ou de confiança da vítima (inciso III); d) quando o crime fosse cometido por quem se aproveitasse do fato de a vítima estar presa ou internada em estabelecimento hospitalar ou sob guarda ou custódia (inciso IV); e) se a vítima fosse considerada juridicamente incapaz (inciso V). (DAI BOSCO, 2001, P. 25)

Infelizmente esse artigo foi cortado na redação aprovada no Senado e estas situações foram reduzidas a um parágrafo único que continha três desses cinco incisos. Mesmo assim, esse parágrafo único foi vetado pelo Presidente da República. O que abriu brecha para uma série de exceções. (Dai Bosco, 2001)

Sendo assim, a Lei número 10.224, de 15 de maio de 2001, criminalizou o assédio sexual no Brasil, introduzindo no Código Penal, Decreto -Lei nº 2.848 de 1940, o delito de assédio sexual, com o seguinte texto:

Art. 216-A. Constranger alguém, com o intuito de obter vantagem ou favorecimento sexual, prevalecendo-se o agente da sua condição de superior hierárquico ou ascendência inerentes ao exercício de emprego, cargo ou função: pena-detenção, de 1(um) a 2 (dois) anos.

Não ignorando o avanço em relação ao tema, pois agora existe uma legislação, mas considerando o aspecto do problema como um todo, essa lei deixou um pouco a desejar. Muitos juristas criticaram o aspecto incompleto da Lei, como por exemplo, o fato de criminalizar somente o assédio que ocorre por parte do superior hierárquico em razão de exercício de emprego. Isso deixa de fora o assédio chamado por intimidação ou assédio sexual ambiental, que prevê a possibilidade de o assediador ser um colega de mesma posição hierárquica na empresa e o assédio sexual que ocorre fora do ambiente das relações trabalhistas, como é o caso dos assédios que ocorrem por pastor ou padre. (Dai Bosco, 2001)

Não menosprezando a Lei que criminaliza o assédio sexual, mas a justiça trabalhista também trata da matéria em questão, sendo assim, se faz necessário falar um pouco sobre o que dispõe a Consolidação das Leis Trabalhistas (CLT).

Branco e Rodrigues (2008) explicam que uma pessoa que comete assédio sexual no ambiente de trabalho deverá ser dispensada por justa causa por descumprir com o que está 
previsto no artigo 482, alíneas a e b da CLT: "Art.482. Constituem justa causa para rescisão do contrato de trabalho pelo empregador: a) Ato de improbidade; e b) Incontinência de conduta ou mau procedimento;",

O empregador responde também pelos atos dos empregados, por isso, ele pode ser responsabilizado se algum empregado da empresa cometer assédio sexual no ambiente de trabalho. Nesse sentido, de acordo com Branco e Rodrigues (2008), pode se aplicar a Súmula 341 do Supremo Tribunal Federal (STF), na qual se afirma a presunção de culpa do patrão em ato culposo do empregado, ou, pode ser aplicado o que diz no artigo 932 inciso III do código Civil que entende que o empregador responde pelos atos de seus empregados.

De acordo com Barros (apud Branco e Rodrigues, 2008) o empregado que for vítima de assédio sexual no trabalho, além de poder acionar a justiça criminal, poderá rescindir indiretamente o seu contrato de emprego devido ao descumprimento por parte do empregado do artigo 483, alíneas 'c', 'd' e 'e' da CLT que diz:

Art. 483 - O empregado poderá considerar rescindido o contrato e pleitear a devida indenização quando:

a) Forem exigidos serviços superiores às suas forças, defesos por lei, contrários aos bons costumes, ou alheios ao contrato;

b) For tratado pelo empregador ou por seus superiores hierárquicos com rigor excessivo;

c) Correr perigo manifesto de mal considerável;

d) Não cumprir o empregador as obrigações do contrato;

e) Praticar o empregador, ou seus prepostos, contra ele ou pessoa de sua família, ato lesivo da honra e boa fama;...

Neste contexto percebe-se que o empregado tem algum amparo pela legislação trabalhista e pelo Código Penal. Contudo, a dificuldade surge no momento de provar que o assédio aconteceu, pois, devido ao fato de que esse crime acontece normalmente em um ambiente privado, onde estão presentes somente a vítima e o assediador, torna-se complicado obter provas que não sejam o depoimento do assediado. Essa dificuldade de provar que o assédio realmente aconteceu faz com que muitas pessoas desistam de denunciar, o que acaba por prejudicar o combate a essa prática criminosa que aterroriza especialmente muitas trabalhadoras e trabalhadores.

As opiniões das entrevistadas e do entrevistado sobre o assédio sexual

A questão do assédio sexual é percebida pelos entrevistados como um grande e velho problema que tem se tornado uma verdadeira barreira para as mulheres no mercado de

\footnotetext{
${ }^{5}$ As citações de artigos da CLT que constam neste capítulo foram retiradas do site: www.presidencia.gov.br
} 
trabalho. É sensível para os entrevistados que a sociedade clama por uma resolução para este empecilho a democracia e igualdade.

Nota-se pela opinião de uma das entrevistadas que a questão da divisão sexual do trabalho ainda repercute de maneira incisiva na vida das mulheres em todos os âmbitos, inclusive o trabalho. A divisão sexual do trabalho, pilar da cultura machista e patriarcal, tem posto uma barreira difícil de dispor para as mulheres no mundo do trabalho, a discriminação.

A coordenadora do Programa de Promoção da Igualdade de Gênero e Raça no Mundo do trabalho, do escritório da Organização Internacional do Trabalho (OIT) no Brasil, Márcia Vasconcelos afirma que o combate a discriminação no trabalho é um dos pilares que norteia a ação das políticas da OIT e nesse combate à discriminação se encontram ações voltadas para as mulheres, que são freqüentemente alvo de práticas discriminatórias.

A entrevistada em questão afirma que a trajetória da OIT em relação ao combate a discriminação de gênero nas relações de emprego se dividem em dois momentos: primeiro momento vai do ano de 1919 até o ano de 1950, que foi quando houve a primeira discussão em torno das mulheres e o mercado de trabalho. Nesse primeiro momento, o debate girava em torno da proteção do trabalho das mulheres em relação à maternidade. No segundo momento, que se deu a partir de 1951, com a convenção 100 buscava-se promover a igualdade de oportunidade para as mulheres no mercado de trabalho. Mas, o marco mesmo para a questão da discriminação foi a convenção 111, nas qual os países que assinavam se comprometiam a erradicar as práticas de discriminação que degradava o mercado de trabalho. Ao longo da entrevista, a Sra. Márcia Vasconcelos, deixou bem claro a preocupação que a OIT tem em relação a discriminação no trabalho e como combater esse problema se encontra num ponto central para essa organização.

Outra instituição que também se preocupa bastante com a discriminação no mercado de trabalho é a SOS Corpo Instituto Feminista para a Democracia, de acordo com a pesquisadora dessa organização, a Sra Verônica Ferreira, "A violência e discriminação que as mulheres sofrem se deve a persistência do sexismo no mundo do trabalho, da cultura patriarcal que desvaloriza o trabalho de nós mulheres, sobretudo nos postos considerados de “natureza masculina”",.

De acordo com a entrevistada, a violência que afeta as mulheres no mercado de trabalho não se expressa somente por atos de agressão física ou psicológica, mas se expressa, principalmente, pela exclusão das mesmas no mercado de trabalho, pela ausência de igualdade de oportunidade, pela nítida dificuldade de acesso a determinados cargos, pela 
visão de que o corpo das mulheres pode ser utilizado pelos homens da maneira que bem entenderem:

\footnotetext{
A violência contra as mulheres no espaço de trabalho se dá tanto pela visão de que este não é um espaço das mulheres ou da concepção de que o corpo das mulheres pode ser violado ou utilizado pelos homens que dá origem a formas de violência como o assédio. (Fala do entrevistado)
}

$\mathrm{Na}$ opinião da entrevistada, as práticas de assédio sexual e moral no trabalho se relacionam diretamente a divisão sexual do trabalho que estrutura as relações sociais de gênero, essas práticas cruéis são uma das expressões da sociedade patriarcal: "O fato das mulheres estarem nos inferiores níveis de hierarquia e a visão naturalizada de que o corpo e a sexualidade das mulheres podem ser violados pelos homens vulnerabilizam as mulheres ao assédio sexual”.

Ferreira afirma que compartilha da mesma visão de divisão sexual do trabalho que Helena Hirata e Danièle Kergoat "Compartilhamos da visão de Hirata e Kergoat de que a divisão sexual do trabalho se baseia em dois princípios: o da separação - existem trabalhos de homem e trabalhos de mulher - e da hierarquia - o trabalho realizado pelo homem vale mais do que o trabalho da mulher. "Esse princípio aparece no mercado de trabalho de forma bem clara, principalmente, quando trata-se de do trabalho reprodutivo, que é ainda realizado muitas vezes pelas mulheres.

Em relação a legislação a entrevistada acredita que as práticas do assédio sexual e moral no trabalho são criminosas e devem ser combatidas. Contudo a legislação brasileira, apesar de ser uma conquista, vem tardiamente: "A legislação é uma conquista, porém tardia."

No tocante a Legislação, ao surgimento da Lei $n^{\circ}$ : 10.224/01, 4 entrevistadas e um entrevistado falaram mais especificamente acerca do processo de nascimento dessa lei e dos fatores que contribuíram para o aparecimento da mesma. Os entrevistados foram: Comba Marques Porto, juíza especializada na área trabalhista; Wolnei Tadeu Ferreira, advogado especializado na área trabalhista; Natália Mori Cruz, assessora parlamentar da Ong CFEMA; Ela Wiecko Volkmer de Castilho, Corregedora- geral do Ministério Público Federal (MPF) e Rita de Cássia Paste Camata, Deputada Federal.

$\mathrm{Na}$ fala desses sujeitos de entrevista vários fatores foram citados como importantes nesse processo de surgimento da referida Lei: a atuação do movimento de mulheres, do movimento feminista, do movimento sindical, dos movimentos sociais em geral, do Conselho Nacional dos Direitos das Mulheres, as recorrentes denúncias expressas tanto na mídia como 
no poder judiciário por meio de ações, os próprios parlamentares representados pela bancada feminista e até A Conferência Mundial sobre as Mulheres em 1995 na China, que representou um marco na busca pela igualdade, justiça social e direitos humanos.

Em todo instante ao longo das respostas dos entrevistados foi ressaltado que foram um conjunto de fatores os responsáveis para o surgimento da referida Lei e não somente um fator x ou y, mas a união de todos eles.

Cada entrevistado deu mais ênfase em determinado fator, a primeira entrevistada, a Sra juíza Comba Marques, destacou nesse processo a importância dos movimentos sociais, em especial, do movimento de mulheres e movimento feminista, sendo comentado também a presença das ONGs. É bem visível a importância desses fatores para a entrevistada quando ela diz:

A criação de tal legislação está indissoluvelmente ligada à atuação histórica do movimento feminista, já que a mulher parece ser numericamente a grande vítima das condutas assediosas. Da mesma forma, após a vigência da Constituição de 1988, a questão amadureceu a partir das políticas públicas em âmbito federal, estadual e municipal postas em prática. O papel das ONGs e demais entidades integrantes do movimento social, notadamente do movimento de mulheres. (Fala da entrevistada)

O segundo entrevistado, o Sr Wolnei Tadeu Ferreira, deu mais ênfase nas denúncias dos casos materializadas na recorrência dos mesmos na justiça, o que faz com que o legislativo percebesse a necessidade da sociedade na criação de determinada norma. Nesse aspecto é importante falar que de acordo com o Ministério Público do Trabalho (MPT), somente do ano passado para o corrente ano 185 procedimentos administrativos e ações judiciais sobre os temas de assédio sexual e moral estão sendo tratadas pelo MPT. Dessas 185, 86 se originaram de denúncias dos próprios trabalhadores, representando quase metade do número de ações. O que mostra que os (as) trabalhadores (as) são os responsáveis pela maior parte das denúncias em relação ao tema. Em seguida vem o Ministério Público do Trabalho (MPT), com 49 denúncias.

Foi citado também por ele a participação dos movimentos sociais. Sendo assim, afirma o segundo sujeito de entrevista:

\footnotetext{
Iniciativa parlamentar, uma vez que o clamor da sociedade já se fazia premente e freqüente nos tribunais, diante do avanço verificado nessas ocorrências. Os movimentos sociais (pressão da sociedade) e a freqüência com que as vítimas levam seus casos aos tribunais são os principais atores neste movimento. (Fala do entrevistado)
}

A terceira entrevistada, Naltalia Mori Cruz, ressaltou também a participação no processo do movimento de mulheres e movimento feminista. Mas também mencionou a participação das sindicalistas feministas, a importância das denúncias recebidas, a atuação das 
Ongs, de representantes governamentais e dos próprios parlamentares, representados pela bancada feminina.

\begin{abstract}
Nos movimentos de mulheres e feministas, o reconhecimento do problema real, vivenciado pelas mulheres, a partir das denúncias e queixas recebidas, ouvidas, tanto no campo nacional, como internacionalmente, fazem com que se gerem demandas para novos direitos. Demanda importante tanto para o movimento feminista quanto para as sindicalistas feministas e demais grupos que pensam as relações de gênero no mundo do trabalho que acompanharam todo o processo de tramitação dessa legislação. Militantes de ONGs, movimento feminista e sindical, junto com o apoio de representantes governamentais, da Bancada Feminina, por exemplo, do Congresso Nacional. (Fala da entrevistada)
\end{abstract}

A quarta pessoa a ser entrevistada foi a Corregedora-geral do MPF, Ela Wiecko. No depoimento desta entrevistada, outra vez foi ressaltado a importância do movimento de mulheres. O papel da mídia foi citado, como um canal de denuncia que a sociedade dispõe para tornar publica essas questões importantes. Foi a primeira entrevistada a mencionar o apoio do Conselho Nacional dos Direitos das Mulheres: "Lembro-me que a demanda veio do movimento de mulheres e que a imprensa falada e escrita se ocupava muito da questão. Quanto ao assédio sexual foram decisivas as mobilizações das organizações de mulheres e o apoio do Conselho Nacional dos Direitos das Mulheres."

A última entrevistada, Deputada Rita Camata, foi quem mais contribuiu com elementos informativos acerca do processo em si. Segundo a Sra Deputada, o projeto de lei que deu inicio a atual Lei de $\mathrm{n}^{\mathrm{o}}: 10.224 / 01$ foi o PL $\mathrm{n}^{\mathrm{o}}: 61$ de 1999, de autoria da deputada Iara Bernardi. Mas esse processo na verdade, reapresentou um PL das ex-deputadas Maria Lima e Marta Suplicy, que foi arquivado com algumas modificações.

De acordo com Camata, o texto na Lei que existe hoje veio de Substitutivo apresentado em plenário pela relatora da matéria, a ex-deputada Zulaiê Cobra. O Substitutivo era mais abrangente que o original e corrigia algumas imperfeições técnicas, como uma melhor definição da conduta que se pretendia punir.

A entrevistada ressaltou como principais atores no processo a bancada feminina, as lideranças do movimento feminista no Parlamento, os movimento sociais e a Conferência Mundial sobre as Mulheres em 1995, que resultou na Declaração de Beijing.

a bancada feminina, acabaram se constituindo nos principais atores durante a apreciação da matéria [...] as demandas do movimento feminista no Parlamento, e as lideranças do movimento atuavam em conjunto com a bancada feminina.[...] os movimentos sociais, e não só do movimento feminista, e A Conferência Mundial sobre as Mulheres em 1995, na China, que resultou na Declaração de Beijing. (Fala da entrevistada) 
Segundo Camata, a tramitação do processo foi rápida, pois, havia um consenso sobre a importância do Projeto. Não aconteceu nenhuma audiência pública e o projeto foi aprovado depois que voltou do Senado.

As informações concedidas pela Sra Deputada Rita Camata foram confirmadas na análise das notas taquigráficas da sessão legislativa. Na justificação do projeto é relatado que o projeto é Substituto e que corrigia algumas imperfeições técnicas como a descrição mais clara da conduta a se punir. É citado também nas notas taquigráficas pelo Deputado José Roberto Batochio que a proposta da Deputada Iara Bernardi é adequada e merece o apoio da "Casa", o que mostra, como já foi citado pela Deputada Camata, que havia um interesse geral na aprovação deste projeto. O movimento feminista é mais uma vez citado no momento da justificação da importância deste projeto, dessa vez é mencionado na fala da Deputada Iara Bernardi, que também diz que é uma reivindicação antiga deste movimento.

Uma breve reflexão acerca de algumas reportagens da internet sobre assédio sexual

O objetivo deste tópico do capitulo "Assédio Sexual” é perceber como a mídia eletrônica tem refletido esse fenômeno que atrapalha a vida de muitos trabalhadores e trabalhadoras no mercado de trabalho brasileiro. Para tanto utilizou-se de reportagens que são postas como Clippings e se encontram no site da Secretaria de Políticas para as Mulheres $(\mathrm{SPM})^{6}$.

No site da SPM se encontram 196 reportagens que se referem de diversas maneiras ao assédio sexual. O primeiro ponto que chama a atenção é a grande quantidade de reportagens que foram publicadas no ano de 2005, foram 100 reportagens, enquanto que no ano de 2004 foram 42, no ano de 2006 foram 35, em 2007 foram 11 e entre 2008 e 2010 foram apenas 5. Aparentemente, o ano de 2005 foi o ano de maior debate acerca do tema.

Ao fazer uma breve análise a respeito das reportagens, percebe-se que grande parte delas se refere de alguma maneira a denúncias de assédio sexual, das 196 reportagens que estão no sítio eletrônico da SPM, 48 comentam em seu conteúdo um caso ou uma denúncia de assédio sexual, isso representa $24,4 \%$ das matérias. Desse quantitativo 38 reportagens apresentam as mulheres com vítimas do assédio sexual e somente 4 reportagens apontam o

\footnotetext{
${ }^{6}$ Página do Site da (SPM): http://200.130.7.5/clip/clipping.php?edt_procura=ass\%E9dio+moral\&B1=Localizar .
} 
homem com vítima. Esses números somente reforçam o que já foi falado, que o sexo feminino é o mais exposto a essa prática criminosa.

Uma tendência assustadora que essas reportagens trazem é a incidência de profissionais da saúde ligados ao crime de assédio sexual. Desse quantitativo de 196 reportagens, 10 são de denúncias de vítimas de assédio sexual que afirmam terem sido assediadas por médicos ou enfermeiros ou até profissionais de radiologia. No próprio site da SPM tem cerca de três reportagens que apresentam estudos sobre o alto índice de acusações de assédio sobre os médicos e traça até um perfil desse agressor.

Esse é o caso da reportagem "Pesquisa: ginecologistas são campeões de assédio sexual" publicada pelo Diário do Grande ABC no dia 14 de julho de 2004. Na reportagem mostra uma pesquisa feita pela UnB (Universidade de Brasília), na qual afirma o perfil do médico que comete essa prática criminosa: "Na maioria dos casos, o agressor é ginecologista, homem, tem entre 50 e 59 anos e trabalha na rede privada de saúde." $\mathrm{Na}$ reportagem foi informado pelo Conselho Regional de Medicina que entre 1989 e 2003 foi cassado o registro de 6 médicos por causa de envolvimento com crimes de assédio sexual. $\mathrm{O}$ autor da pesquisa, Júlio Cézar Meirelles, explicou que não somente ginecologistas assediam pacientes: "O levantamento analisou ainda casos de assédio envolvendo profissionais de clínica médica, ortopedia e traumatologia, psiquiatria, cirurgia plástica, pediatria, anestesiologia, medicina do trabalho, neurologia, oftalmologia e cardiologia."

O mais assustador nesse aspecto é que muitos médicos acabam saindo impunes, mesmo existindo essa tendência de grande envolvimento da classe em casos de assédio sexual. É o que mostra outra reportagem do site da SPM, "Assédio sexual de médicos é crime quase impune” publicada pelo jornal Globo On line no dia 15 de julho de 2004. O professor e autor da pesquisa, Júlio Cezar Meirelles, afirma “Apenas 4,2\% dos médicos denunciados por assédio sexual ao Conselho Federal de Medicina (CFM) entre 1997 e 2001 foram condenados." O autor da pesquisa explica que isso ocorre muitas vezes por que é difícil o julgamento desses casos, pois, não há provas documentais, somente a palavra do médico contra o paciente.

Outro ponto interessante que nota-se nas reportagens de assédio sexual que se encontram no sitio eletrônico da SPM é que não somente os médicos saem impunes das queixas de assédio sexual, na verdade, o que se percebe pelas reportagens é que o índice de pessoas que são condenadas por esse crime é pequeno e isso desencoraja as vítimas a denunciar. É o que mostra a reportagem: "Assédio sexual e justiça" publicada pela Folha de 
São Paulo no dia 08 de junho de 2005. Na matéria, Luiza Nagib Eluf afirma que pesquisas têm demonstrado que vítimas de assédio sexual têm recorrido pouco a justiça e isso devido ao fato de que as chances de êxito em relação a punição do culpado são poucas. Assim afirma a repórter:

\begin{abstract}
No entanto, pesquisas realizadas nas Delegacias de Defesa da Mulher e nos Juizados Especiais Criminais demonstram que as vítimas de assédio sexual têm recorrido pouco para fazer valer seus direitos. Talvez porque as chances de sucesso não sejam muito animadoras e as razões para isso continuam sendo o preconceito contra a mulher, que é a ofendida na esmagadora maioria dos casos, e as dificuldades de produção de provas.
\end{abstract}

Esse preconceito mencionado pela repórter muitas vezes está presente também na mente das próprias mulheres. É o que mostra essa mesma reportagem ao trazer um caso de uma juíza que absolve o acusado de assédio sexual e ainda afirma que ser chamada de gostosa pelo superior hierárquico no ambiente de trabalho não configura assédio e sim elogio. $\mathrm{O}$ acusado foi absolvido apesar de chamar a empregada subordinada de gostosa e de fazer vários convites e outras insinuações que foram comprovadas por e-mail.

Mesmo quando o agressor é culpado, normalmente há um abrandamento da pena, as autoridades optam por aplicar penas alternativas. É o que mostra a reportagem "Opção por penas alternativas" do Jornal de Brasília que foi publicada no dia 22 de maio de 2005. Segundo a delegada Rosana Gonçalves, no caso de se conseguir comprovar o assédio, o criminoso, normalmente, é condenado à doação de cestas básicas. "Caso fique comprovado que houve assédio sexual, o autor, geralmente, é condenado à doação de cestas básicas ou a prestação de serviços comunitários. Embora prevista em lei, a detenção é muito rara...” $\mathrm{O}$ pior é que, de acordo com a reportagem, esse é o tratamento que o Poder Judiciário dá aos crimes contra a mulher em geral.

Contudo, ao se analisar outras reportagens do site da SPM percebe-se que essa tendência está mudando, lentamente, mas está mudando. Das 196 matérias que se encontram no site da SPM, 11 comentam mudanças no Código Penal no sentido de superar certas claúsulas muito antigas e machistas que ainda se encontravam no Código Penal. Um exemplo disso é a reportagem "CCJ da Câmara extingue crimes de adultério e sedução" do jornal O Estado de São Paulo que foi publicada no dia 16 de setembro de 2004. A reportagem fala da aprovação pela Comissão de Constituição e Justiças (CCJ) de várias mudanças no Código Penal, mudanças que extinguem os crimes de adultério e sedução e que revogam o perdão para casos de estupro e assédio sexual que a vítima se casa depois. Na reportagem fala que o texto original foi apresentado por entidades da sociedade civil para modernizar o Código 
Penal: "Uma das medidas, por exemplo, é a eliminação de expressões que embutem algum tipo de discriminação, como "mulher honesta"”,

Outro ponto importante que é mostrado nas matérias no sitio eletrônico da SPM são os dados apresentados nas reportagens. É assustador como o número de mulheres que já sofreram assédio sexual é grande, na reportagem “Assédio sexual aumenta no país” publicada pelo jornal Diário da Manhã no dia 4 de setembro de 2006, a Organização Internacional do Trabalho (OIT) divulga estudo que diz que $52 \%$ das trabalhadoras brasileiras já foram assediadas sexualmente.

Outro fator interessante que as reportagens do sitio eletrônico da SPM trouxeram foi em relação ao assédio sexual que ocorre entre colegas de trabalho de mesma posição hierárquica. A despeito do que diz a Lei de Assédio sexual, Lei no: 10.224/01, o poder judiciário está considerando atualmente assédio sexual entre colegas de trabalho de mesma hierarquia. É o que diz na reportagem "Para TRT, assédio é crime mesmo entre colegas" do jornal O Estado de São Paulo que foi publicado no dia 4 de junho de 2005. A matéria fala de uma inovação da jurisprudência em relação ao assunto, na qual uma decisão do Tribunal Regional do Trabalho (TRT) admite assédio entre colegas que exercem funções equiparadas. Na reportagem fala: “Os juízes paulistas consideram que há assédio também na relação entre quem exerce funções que se equiparam. De acordo com o processo, o empregado-que era auxiliar de pessoal- foi demitido em virtude do teor de e-mails que enviava para suas colegas."

As reportagens no site da SPM mostram de forma geral que em se tratando de assédio sexual o Brasil passou por avanços e retrocessos e a mídia tem se encarregado de mostrar isso. O papel desempenhado pela imprensa tem se mostrado de fundamental importância no sentido de refletir os fenômenos que atingem a sociedade e provocá-la a ação. 


\title{
Capítulo IV. ASSÉDIO MORAL
}

\author{
Contextualizando e Definindo o Assédio Moral
}

De acordo com Heloani (2005) a manifestação do fenômeno do assédio moral não é novidade da sociedade contemporânea, mas a sua visibilidade é sim um fator novo. O Brasil na época da colonização, onde índios e negros eram assediados, melhor dizendo, eram humilhados pelos colonizadores, representa um ótimo exemplo. Sendo assim, o autor defende que "considerando a atual sociedade brasileira nos moldes da escravocrata, pensamos que a humilhação no trabalho, ou o assédio moral, sempre existiu, historicamente falando, nas mais diferentes formas”. (HELOANI, 2005, p. 102)

As origens do assédio moral como interesse de estudo se remetem a meados de 1996, tendo como precursor o psicólogo do trabalho, Heinz Leymann. De acordo com Zaneti (2008) o assédio moral é consequiência de um estudo científico realizado por Heinz Leymann e seu grupo de pesquisa, por meio de entrevistas com trabalhadores, onde percebeu-se certos fatos ocorridos no ambiente de trabalho e seus efeitos sobre a saúde dos mesmos.

Zaneti (2008) fala também de outros autores que foram extremamente importantes no nascimento do conceito do assédio moral, como: o doutor Klaus Niedl, autor da primeira tese de doutorado sobre o mobbing, Marie-France Hirigoyen, Harald Ege e o alemão Dieter Zapf.

Estes autores contribuíram sobre maneira para o aperfeiçoamento da teoria do assédio moral na ambiente de trabalho na Europa. Dentre esses autores, a autora que mais se destaca é Marie-France Hirigoyen, que é psiquiatra e psicanalista. Alguns estudiosos do tema afirmam que foi ela quem trouxe mais visibilidade para o assédio moral.

Sabe-se que o fenômeno do assédio moral não é recente, como bem afirma Heloani (2005), mas o mesmo não se pode dizer do próprio termo e dos estudos científicos acerca deste termo. De acordo com Vera Lúcia de Souza (2008) a expressão que levou a atual denominação do conceito de assédio moral nasceu no Reino Unido, denotando qualquer situação em que o empregado é insultado.

De acordo com Souza (2008) cada país tem um termo próprio para designar o assédio moral: mobbing é a expressão mais usada na Europa, bullying é o termo mais falado na Inglaterra, moral harassmente é o mais utilizado nos Estados Unidos, Ijime no Japão, psicoterror laboral ou acoso moral na Espanha, harcèlement moral na França. Em países de língua portuguesa os termos falados são assédio moral, violência moral, tortura psicológica ou terror psicológico. 
No Brasil, de acordo com Souza (2008), a denominação dessas práticas gerenciais de humilhação proposital do trabalhador ocorreu por volta do ano 2000 e serviu como espécie de divisor de águas, fazendo com que a sociedade brasileira visualizasse essas práticas não mais como atos isolados, e sim, como atos de violência, como formas da injustiça organizacional se manifestar.

De acordo com a autora em questão, ao acompanhar a trajetória do conceito no Brasil, percebe-se que a ampliação da percepção da sociedade quanto ao desrespeito à figura do trabalhador se deu em grande parte devido às contribuições do direito do trabalho. Essas contribuições aconteceram sob a inspiração das idéias européias a respeito dos direitos humanos, essa parte do conhecimento científico colaborou com a edificação das bases da nomeação do conceito de assédio moral no Brasil.

De uma maneira geral, o fenômeno do assédio moral é compreendido como um conjunto de ações que degradam o meio de convivência do trabalho. Há autores que definem o assédio moral de uma maneira mais detalhada, explorando assim já os elementos que caracterizam esse fenômeno. Como é o caso de Zaneti (2008) que define assédio moral como:

... intenção de uma ou mais pessoas praticarem, por ação ou deixarem de praticar por
omissão, de forma reiterada ou sistemática, atos abusivos ou hostis, de forma
expressa ou não, contra uma ou mais pessoas, no ambiente de trabalho, durante a
jornada de trabalho e no exercício de suas funções, principalmente por superiores
hierárquicos, após, colegas ou mesmo por colegas e superiores hierárquicos e em
menor proporção, entre outros, por inferiores hierárquicos e clientes, durante certo
período de tempo e com certa frequiência, os quais venham atingir a saúde do
trabalhador, após o responsável ter sido comunicado a parar com eles e não ter
parado. (ZANETI, 2008, P. 27)

A partir desse conceito, o autor em questão pretende já explorar as características que compõem o assédio moral. Sendo assim, Zaneti (2008) explica que, na sua concepção, para que aconteça o este fenômeno é necessário estarem presentes os seguintes quesitos: a realização ou não de ato abusivo ou hostil; a repetição; a frequiência; a duração; a intenção do assediador na realização das práticas hostis; serem considerados os aspectos culturais; o objetivo do assediador, que pode ser simplesmente abalar psicologicamente outra pessoa ou fazer com que ela não trabalhe mais com ele; ser atingida a saúde do assediado e, por fim, que a prática ocorra no ambiente de trabalho, durante a jornada de trabalho e no exercício de suas funções.

Há autores que definem o assédio moral de uma maneira mais simples, mas contemplando a maioria desses quesitos apontados por Zaneti (2008), como é o caso de Barreto (Barreto apud Caniato e Lima, 2008) que conceitua o termo da seguinte maneira: 
...o assédio moral ou a violência moral no trabalho são a exposição de trabalhadores a situações vexatórias, constrangedoras e humilhantes, de forma repetitiva no exercício da função, caracterizando atitudes desumanas, violentas e antiéticas de um ou mais chefes contra o subordinado. (BARRETO apud CANIATO \& LIMA, 2008, P. 182)

Caniato e Lima (2008), após um diálogo com vários autores acerca do tema, chegam a sua própria concepção do que é assédio moral:

\begin{abstract}
...uma violência psíquica, um cerceamento da autonomia do indivíduo e da constituição de vínculos de alteridade, que se caracteriza, fundamentalmente, pelo domínio e controle da ação laboral do sujeito social. No âmbito da organização produtiva, mais que a espoliação da força de trabalho e as restrições às suas condições materiais de sobrevivência, as adversidades impostas aos indivíduos exprimem a expropriação da possibilidade humana de tornar-se protagonista de sua própria existência, de singularizar-se e de desenvolver a sua alteridade em laços de confiabilidade e acolhimento com seus semelhantes. (CANIATO \& LIMA, 2008, P. 191)
\end{abstract}

Essas definições tendem a considerar o fenômeno mais direcionado a uma lógica individual do problema. Existem autores que defendem que o problema se relaciona também diretamente a organização num processo de construção sócio-histórica, um exemplo de autor que discute o problema nessa direção é o auto Roberto Heloani.

O Heloani (2005) deixa explícito que adota outra concepção que ao invés de considerar o assédio moral como individual, considera que cada pessoa é produto de uma construção sócio-histórica.

$\mathrm{Na}$ concepção do autor em questão, todo esse contexto no qual está envolvido o trabalhador atualmente, contexto de reestruturação produtiva, de precarização das relações de trabalho, de substituição rápida da mão-de-obra por máquinas, de novas relações de contrato de trabalho trazendo à tona a terceirização e os subempregos, reflete nas ações do trabalhador.

Como o próprio autor diz: "Se for certo que o furor expansionista do capital conquistou-nos financeiramente, é também exato que nesse processo de expansão comprometeu-se o nosso discernimento, ou melhor, a nossa saúde moral" (HELOANI, 2005, P.103).

Para esse autor o assédio moral é instigado pelo atual contexto de trabalho, o qual os novos modos de produção capitalista e a ideologia neoliberal incentivam a hipercompetitividade e onde o assédio moral é visto como um instrumento de neutralizar o outro, aquele que parece ameaçar a posição do assediador.

De acordo com essa vertente, mais direcionada ao contexto maior do mercado de trabalho, Heloani (2005) define assédio moral como: 
...consiste na constante e deliberada desqualificação da vítima, seguida de sua conseqüente fragilização, com o intuito de neutralizá-lo em termos de poder. Esse enfraquecimento psíquico pode levar o indivíduo vitimizado a uma paulatina despersonalização. Sem dúvida, trata-se de um processo disciplinador em que se procura anular a vontade daquele que, para o agressor, se apresenta como ameaça. (HELOANI, 2005, P. 104)

Essa visão do assédio moral defendida por Heloani (2005) é contestada por outros autores, dentre eles a psiquiatra e psicanalista Marie-France Hirigoyen. Hirigoyen (2006), que é uma grande estudiosa da temática e que é utilizada por muitos autores brasileiros, acredita que não se pode culpar somente a globalização e os processos de reestruturação produtiva pelo fenômeno do assédio moral.

Para a autora em questão, a intencionalidade vem das pessoas que dirigem ou tiram partido dos sistemas perversos. Não são as reestruturações e a globalização em si que criam esse fenômeno destruidor, mas sempre vão existir empregados com muitas ambições de poder que se aproveitarão de qualquer situação para subir de cargo na empresa, mesmo que seja até uma reorganização ou modificação na estrutura do mercado de trabalho.

Em síntese pode-se dizer que para Hirigoyen

...o assédio moral no trabalho é definido como qualquer conduta abusiva (gesto, palavra, comportamento, atitude...) que atente, por sua repetição ou sistematização, contra a dignidade ou integridade psíquica ou física de uma pessoa, ameaçando seu emprego ou degradando o clima de trabalho. (HIRIGOYEN, 2006, P. 17)

Na interpretação de Hirigoyen (2006), o assédio moral surge como algo sutil, algo que inicialmente não é interpretado como algo maldoso, é visto como inofensivo. Ele se espalha de forma sorrateira, sendo que, no inicio as duas pessoas envolvidas tentam evitar o conflito. $\mathrm{O}$ assediador (a) age de maneira discreta, com indiretas, toques sutis, evitando o conflito declarado. $\mathrm{O}$ assediado (a), na tentativa de fugir do confronto, tenta não demonstrar se sentir ofendido (a). Com o passar do tempo, os ataques vão aumentado e a vítima vai se sentido sem saída, se sentido inferior, se encontrando em situações hostis como mais frequiência e por mais tempo, até que se chega ao ponto da violência explícita.

Depois da fase de violência explícita, de acordo com Hirigoyen (2006), vem à fase da violência fria, que é repleta de injúrias, humilhações verbais, de menosprezo por tudo que se relaciona a vítima. Todo esse jogo maldoso tem o objetivo de levar a vítima a uma violência e aberta, explícita, fazendo assim com que o assediado/a se sinta culpado/a.

Hirigoyen (2002) no seu livro "Assédio moral: a violência perversa no cotidiano" tende a caracterizar o assediador como uma pessoa cruel, perversa, e o assediado seria aquela pessoa que tem um caráter pré-depressivo. Contudo a vítima não seria propriamente uma 
pessoa depressiva, mas uma pessoa que possui esse traço na personalidade e o agressor vai utilizar dessa fraqueza.

Entretanto, no seu segundo livro sobre a temática, "Mal-Estar no trabalho: redefinindo o Assédio Moral", Hirigoyen (2006) explica melhor sobre a vítima do assédio moral e a pessoa que comete essa prática. A autora pondera que o assediado não precisa necessariamente ter uma característica depressiva para ser vítima de assédio, mas no geral essa pessoa tem um perfil ou um atributo que a diferencia dos demais e isso incomoda algumas pessoas.

Hirigoyen (2006) afirma que o assédio começa freqüentemente pela recusa de uma diferença, se apresenta por um comportamento próximo a discriminação: "Provavelmente, da discriminação chegou-se ao assédio moral, mais sutil e menos identificável, a fim de não correr o risco de receber uma sanção." (HIRIGOYEN, 2006, P. 38)

Talvez seja pelo fato de o assédio possuir esse caráter discriminatório que as vítimas mais freqüentes dele são as mulheres. De acordo com um levantamento de dados feitos por Hirigoyen (2006) no seu livro "Mal-Estar no trabalho: redefinindo o Assédio Moral" de um total de 193 entrevistados que diziam ter sofrido assédio moral no trabalho $70 \%$ eram mulheres e $30 \%$ eram homens.

A autora em questão ressalta que esses dados variam de acordo com o contexto sociocultural onde ocorre a pesquisa. De acordo com Hirigoyen (2006) os países escandinavos e a Alemanha demonstram muita preocupação com a igualdade entre os sexos e, por isso, os dados desses países referentes a pesquisas de pessoas que sofrem assédio moral tendem a ser mais equilibrados entre os dois sexos. Já nos países como a Itália, Espanha e os países da América Latina, onde a cultura machista ainda domina a sociedade, a tendência é que as pesquisas demonstrem uma porcentagem maior de mulheres que sofrem assédio moral.

Hirigoyen (2006) afirma que não somente as mulheres são as vítimas mais freqüentes, mas também são assediadas de forma diferente dos homens. As agressões são normalmente com conotações sexistas e machistas. A autora chega a considerar que o assédio sexual se enquadra dentro do assédio moral, nos dois casos trata-se de humilhar o outro e considerá-lo um objeto a disposição.

Não bastasse a forma diferente com que ocorre o assédio moral a depender das características da vítima, existem também tipos diferentes desse fenômeno. Hirigoyen (2006) identifica 4 tipos diferentes de assédio moral: 1. o assédio vertical descendente, 2. o assédio horizontal, 3. o assédio ascendente e o 4 . assédio misto. 
O primeiro tipo de assédio, o vertical descendente, refere-se aquele que é cometido por um superior hierárquico contra um subordinado, abusando do seu poder de chefia. A autora em questão afirma que este tipo de assédio tem conseqüências mais graves sobre a saúde do trabalhador do que os outros.

O segundo tipo de assédio, o horizontal, é aquele cometido por colegas de posição hierarquicamente equivalentes na empresa e acontece normalmente quando os dois empregados disputam o mesmo cargo ou promoção.

O terceiro tipo de assédio, o ascendente, ocorre quando a vítima do assédio é um superior hierárquico e o assediador é um ou mais subordinados deles, esse tipo normalmente não é levado muito em consideração, mas pode ser tão destrutivo quanto os outros.

O quarto tipo de assédio, o misto, é uma mistura dos outros tipos, ocorre tanto numa relação de hierarquia como em uma relação de hierarquias equivalentes. Nesse tipo de assédio está presente a figura do grupo que aprova a posição do assediador ou no mínimo se omite diante dela.

Esse antigo problema com sua recente evidência devem ser combatidos para o bem dos trabalhadores, das empresas, da sociedade em geral, e para que isso ocorra é importante continuar o debate. Muitas vezes é por meio do diálogo e da reflexão que se chega a solução dos problemas.

\section{Legislação sobre o Assédio Moral}

Em relação à legislação sobre o assédio moral no Brasil é notório um certo atraso do país, tendo em vista que, o mesmo não possui ainda nem uma lei que disciplina esse problema em âmbito nacional e muitos países já possuem leis de âmbito nacional que reprimem essa prática maldosa, países como: Alemanha, Itália, França, Estados Unidos, Suíça.

Mesmo não existindo nenhuma lei de âmbito nacional que discipline essa matéria, não significa que as pessoas que sofrem com o assédio moral estão completamente desprotegidas. De acordo com Souza (2008) até o ano de 2008 já existia em vigor mais de 50 projetos de lei aprovados no âmbito municipal e estadual e de acordo com Natalia Mori Cruz, assessora parlamentar da ONG CFEMEA, entre 2001 e 2009 foram apresentadas 6 proposições $^{7}$ ao Congresso Nacional sobre essa temática.

\footnotetext{
${ }^{7}$ Informação obtida por meio de uma entrevista concedida por Natalia Mori Cruz a esta pesquisadora.
} 
De acordo com Zaneti (2008) a primeira aparição da proteção legal que dispunha sobre o assédio moral no Brasil foi no âmbito da administração direta, por meio da apresentação do Projeto de Lei no: 425/1999 que surgiu da Câmara Municipal de São Paulo, desse projeto de Lei surgiu a Lei $n^{\text {o: }} 13.288$ de 2002. Apesar de este projeto citado ser a primeira aparição no legislativo, não foi o primeiro a ser aprovado. De acordo com o autor, o município de Iracemápolis foi o primeiro a publicar a primeira lei sobre o assédio moral, Lei $\mathrm{n}^{\mathrm{o}}: 1.163 / 2000$, contudo, esta se restringe aos servidores públicos.

No âmbito estadual, o Estado do Rio de Janeiro foi o primeiro a criar uma Lei contra o assédio moral, de acordo com Zaneti (2008). Essa referida Lei foi a de $n^{\text {o: }}$ 3.921/2002 que proibia a prática de assédio moral nos órgãos estatais.

Embora não exista ainda uma legislação de âmbito federal que condene as práticas de assédio moral, o trabalhador que sofre com esse fenômeno não se encontra amparado somente em legislações municipais e estaduais, há mecanismos na própria Constituição Federal de 1988 que servem como fundamento legal de defesa do trabalhador.

De acordo com Zaneti (2008), um dos artigos principais da Constituição Federal (CF) que fala dos direitos sociais dos trabalhadores é o art. $7^{\circ}$, esse artigo é um ótimo exemplo de proteção constitucional que o trabalhador que sofre assédio moral pode utilizar. O inciso XXII deste artigo se aplica perfeitamente a esse caso, pois diz:

\footnotetext{
Art. $7^{\circ}$ São direitos dos trabalhadores urbanos e rurais, além de outros que visem à melhoria de sua condição social:

[...] XXII - redução dos riscos inerentes ao trabalho, por meio de normas de saúde, higiene e segurança. (Constituição Federal da República de 1988)
}

Este artigo é um bom exemplo de amparo legal para o trabalhador, pois, obrigam o empregador a garantir um meio ambiente saudável para o empregado, um meio ambiente seguro, sadio e sem fenômenos maldosos que causem qualquer tipo de dano a saúde do trabalhador. (Zaneti, 2008)

Tendo em vista que o assedio moral possuí a mesma natureza discriminatória do assédio sexual, pode-se também aplicar as mesmas medidas legais do assédio sexual que já foram citadas: art. 482 da CLT, alíneas 'a' e 'b'; art. 483 da CLT, alíneas 'c', 'd' e 'e'; súmula 341 do STF e art. 932, inciso III do Código Civil. 
As opiniões das entrevistadas e do entrevistado sobre o assédio moral

Da mesma maneira que a questão do assédio sexual é percebida pelos entrevistados como um grande e velho problema, o assédio moral também. Nota-se que para os entrevistados a sociedade clama por uma resolução para mais este empecilho a democracia e igualdade.

A maioria dos relatos cedidos pelos sujeitos de entrevista em relação ao assédio sexual se repetem no assédio moral. A questão da divisão sexual do trabalho, que foi colocada pela participante de pesquisa, Verônica Ferreira, pesquisadora da Sos Corpo Instituto Feminista para a Democracia, também se aplica ao assédio moral, devido ao seu caráter discriminatório. Como diz Hirigoyen (2006) "Provavelmente, da discriminação chegou-se ao assédio moral, mais sutil e menos identificável...” (HIRIGOYEN, 2006, P. 37)

Diante disso, Verônica Ferreira, afirma que as mulheres também são normalmente vítimas freqüentes do assédio moral. A participante de pesquisa acredita que isso ocorre devido ao maior poder dos homens nas relações sociais e o modo como a sociedade patriarcal se coloca faz com que as mulheres se encontrem em uma situação de vulnerabilidade. Afirma a entrevistada:

Pelo que conhecemos acerca do problema, são sobretudo as mulheres que enfrentam este tipo de violência, uma vez que é uma prática, na nossa visão, que têm a ver com maior poder dos homens nas relações sociais de gênero, sobretudo no caso do assédio sexual e mesmo no caso do assédio moral. (Fala da entrevistada)

A entrevistada acredita que as práticas de assédio moral estão relacionadas ao fato de que as mulheres se encontram nos inferiores níveis de hierarquia e o assédio moral é utilizado várias vezes para demonstrar poder sobre a outra pessoa, demonstrar hierarquia: “ $O$ assédio moral é muitas vezes utilizado para demonstrar hierarquia e tolher a ascensão das mulheres no espaço de trabalho, como muitas trabalhadoras com as quais trabalhamos demonstram."

Devido ao fato de que os dois tipos de assédio possuem suas raízes baseadas na discriminação, a autora confirma o que outros estudiosos do tema já tem apontado, o assédio moral pode vir precedido do assédio sexual não correspondido, o que acontece com mais freqüência, e pode também preceder o assédio sexual. É o que afirma a entrevistada:

O assédio moral pode preceder e suceder ao assédio sexual. Preceder no sentido de que a prática do assédio sexual pode se valer do mecanismo de assédio moral para fins de ser bem-sucedido, sobretudo quando há resistência. E pode suceder exatamente quando, não conseguindo ser "bem-sucedido" no assédio sexual, se empregue o assédio moral como mecanismo de retaliação ou mesmo para coibir a denúncia de quem sofreu este tipo de violência. (Fala da entrevistada) 
Apesar de serem fenômenos que possuem um ponto em comum, que é a discriminação, existem diferenças entre eles, principalmente, no que se refere a legislação. Enquanto o assédio sexual possui uma Lei de âmbito nacional (Lei $n^{\circ}$ : 10.224/01), o assédio moral não. A expressão do fenômeno assédio moral é mais recente.

A entrevistada Natália Mori Cruz, assessora parlamentar da Ong CFEMEA identifica alguns pontos que divergem dessas duas práticas cruéis, inclusive no que se refere ao processo de surgimento da legislação. De acordo com entrevistada, o tema assédio moral foi bastante abordado no Congresso Nacional, no período de 2003 a 2009, isso em termos de debates, audiências publicas e tramitação em comissões. O que diferencia do processo de surgimento da Lei 10.224/01, que foi aprovada mais rapidamente, sem necessitar de audiências públicas. Segundo Natália Mori, a Ong CFEMEA tem articulado bastante sobre o tema, sempre buscando mostrar as preocupações de gênero sobre esse assunto. Embora o projeto de lei $n^{\circ}: 2.369 / 03$ tenha suas diferenças em relação a Lei 10.224/01, a entrevistada considera que os fatores que foram importantes para o surgimento da primeira lei também se aplicam ao surgimento do projeto de $n^{\circ}: 2.369 / 03$ :

Toda ação de advocacy (promoção e defesa de direitos), quero dizer, de incidência política feita em articulação que explicava na primeira pergunta. Militantes de ONGs, movimento feminista e sindical, junto com o apoio de representantes governamentais, da Bancada Feminina, por exemplo, do Congresso Nacional. (Fala da entrevistada)

A entrevistada Comba Marques, juíza especializada na área trabalhista, também elenca os mesmos fatores de surgimento da Lei de $\mathrm{n}^{\mathrm{o}}$ : $10.224 / 01$ para o projeto de lei $\mathrm{n}^{\mathrm{o}}: 2.369 / 03$. Que seriam: a atuação do movimento feminista, o papel das Ogns, dos movimentos sociais, do movimento de mulheres e das entidades sindicais. Marques acredita que as tramitações que estão no Congresso Nacional logo se tornarão Lei e que isso irá reforçar o campo das garantias gerais do direito ao trabalho.

O entrevistado Wolnei Tadeu Ferreira, advogado especializado na área trabalhista, diverge um pouco da opinião da entrevistada Natália Mori Cruz. Segundo ele, não há grandes diferenças no tocante ao processo de surgimento das referidas Legislações. De acordo com Tadeu Ferreira: "Na verdade, não há grandes diferenças, no meu modo de ver, haja vista que ambas nasceram e tiveram o princípio decorrente da pressão da sociedade, para que tais medidas fossem reguladas." Sendo assim, ele continua elencando com fatores importantes para o surgimento desse projeto de lei uma união de esforços, os movimentos sociais (que 
representam a pressão da sociedade) e a frequiência com que as vítimas levam seus casos aos tribunais.

Outra entrevistada diverge do ponto de vista do Sr Wolnei Tadeu Ferreira, a Corregedora-Geral do Ministério Público Federal, Ela Wiecko Volkmer de Castilho. De acordo com Castilho, o processo de surgimento do Projeto de Lei $n^{\circ}$ : 2.369/03 teve um fator desencadeante diferente do da Lei $n^{\circ}$ : 10.224/01 e está tendo um processo de criação diferente. Enquanto que no caso do Projeto de Lei $n^{\text {o: }}$ 61/99, que deu origem a lei $n^{\text {o: }}$ 10.224/01, os principais fatores citados por Castilho foram os movimentos feministas, os movimentos de mulheres, no caso do projeto de Lei $\mathrm{n}^{\mathrm{o}}$ : 2.369/03, o fator determinante apontado pela entrevistada é a pressão dos sindicatos.

Ao contrário do que aconteceu com o projeto de Lei $n^{\circ}$ : 61/99, que, segundo a entrevistada Sra. deputada Rita Camata, foi aprovado sem que houvesse muita oposição, o desenrolar do processo de criação do projeto de Lei $\mathrm{n}^{\mathrm{o}}: 2.369 / 03$ não tem seguido os mesmos passos, de acordo com a Sra. Castilho há fatores que estão atrapalhando o andamento e a entrevistada aponta como causa disso os interesses dos empregadores.

Torna-se necessário ressaltar que não há ainda muitas informações a respeito do nascimento e do desenrolar desse projeto de Lei por que ele ainda está acontecendo, os fatos ainda estão se consolidando e não há nem como saber se o projeto de Lei no: 2.369/03 será mesmo aprovado e virará Lei. Atualmente o projeto se encontra na Comissão de Trabalho, Administração e Serviço Público e está Sujeito a Apreciação Conclusiva pelas Comissões.

Uma breve reflexão acerca de algumas reportagens da internet sobre assédio moral

O objetivo deste tópico do capitulo "Assédio Moral" é perceber como a mídia eletrônica tem refletido esse fenômeno que está cada vez mais evidente no mercado de trabalho brasileiro. Para tanto utilizou-se de reportagens que são postas como Clippings e se encontram no site da Secretaria de Políticas para as Mulheres (SPM).

Inicialmente o que mais chama atenção é o aumento gradativo de matérias sobre o assunto que começa em 2004 e se interrompe em 2007. Das 92 reportagens que se encontram nesse sítio eletrônico apenas três são do ano de 2003, sendo que de 2003 para 2004 há um aumento de dez reportagens e deste ano para 2005 as reportagens mais que dobram, são apresentadas 30 reportagens do ano de 2005. No ano de 2006 as reportagens se mantêm 
quase no mesmo número de 2005, são apresentadas 31 reportagens no ano de 2006. No ano de 2007 há uma queda no número de matérias, são mostradas somente 15, e no ano de 2008, 2009 e 2010 não é apresentada nenhuma reportagem nesse sítio eletrônico.

É interessante notar que a percepção do fenômeno pela mídia é recente e acompanhou o processo de conceituação do termo no país. Como já foi falado, o termo assédio moral, designando práticas gerenciais de humilhação proposital ao trabalhador, surgiu no Brasil por volta do ano de 2000 (Souza, 2008). A denominação do termo levou a sociedade a perceber esse problema não mais como um problema individual, mas sim, como uma prática cruel que esta cada vez mais presente na vida dos trabalhadores e que precisa ser denunciada. A partir daí a mídia começou a dar mais atenção para a questão e a sociedade começou a denunciar mais essa prática injusta.

Esse aumento gradativo no número de denúncias de assédio moral pode ser visualizado até pelo teor das reportagens que saem sobre o tema. Das 92 reportagens que se encontram no site da SPM 21,7\% comentam sobre casos que foram denunciados de assédio moral ou sobre decisões judiciais referentes a denuncias feitas ao judiciário.

As próprias matérias que saem sobre o assunto ressaltam esse aumento no número de denúncias. Das 92 reportagens do sitio eletrônico da SPM, 9 falam justamente do crescimento de denúncias de assédio moral. Como é o caso da reportagem "Crescem ações e denuncias de assédio moral" do jornal Valor Econômico, publicada no dia 29 de junho de 2007. Nessa matéria, Felipe Frisch afirma sobre o crescimento do número de denúncias baseado na fala da advogada Karla Bernardo. Esta comenta dados do Ministério Público do Trabalho (MPT): "Lançando mão de dados do Ministério Público do Trabalho (MPT), a advogada lembra que o órgão abriu 337 investigações no ano passado (2006) para apurar casos de assédio denunciados e supostamente praticados por empresas de diversos setores...".

Esse mesmo número é reforçado em outra matéria que também fala do aumento do número de denúncias. O jornal Folha de São Paulo publica no dia 17 de dezembro de 2006 a matéria "Crescem denúncias de assédio moral no país" na qual afirmam o mesmo número citado na matéria anterior e tecem uma comparação com o número de denúncias do ano anterior: "Só neste ano o Ministério Público do Trabalho abriu 337 investigações (mais que o dobro das instauradas em 2005) para apurar casos de assédio denunciados em empresas dos setores têxtil, cosmético, farmacêutico, químico, metalúrgico, financeiro e estatal."

Outro ponto que nota-se nessas reportagens e que reforça o que já foi dito ao longo deste trabalho é o fato das mulheres se com frequiência as maiores vítimas do assédio moral. 
Das 20 reportagens que comentam casos que foram denunciados e decisões judiciais que foram tomadas, 14 mostram a mulher com vítima do assédio moral, contra 2 que mostram homens como vítima e 4 que falam sobre assédio moral coletivo.

O fato de a mulher fazer parte do grupo de pessoas mais suscetíveis ao assédio moral já foi notado pela mídia que também faz reportagens sobre isso. Como é o caso da matéria "Assédio moral atinge mais as mulheres" publicada pelo jornal A Crítica no dia 13 de maio de 2007. Na reportagem afirmação de que a mulher é mais atingida que o homem pelo assédio moral no trabalho é baseada na fala de Sônia Maria Zerino da Silva, secretária para Assuntos de Trabalho da Mulher, do Idoso e do Adolescente da Confederação Nacional dos Trabalhadores na Indústria (CNTI). A mesma afirma que diversas são as situações em que as mulheres sofrem o assédio, mas uma situação frequiente se relaciona as atribuições delas no que se refere à reprodução social: “As situações são as mais diversas, principalmente quando a mulher retorna da licença maternidade e faz valer o seu direito de amamentar o bebê." Essas informações foram dadas para o jornal no $1^{\circ}$ Encontro de Mulheres Trabalhadoras na Indústria do Estado do Amazonas.

As reportagens do site da SPM demonstram que, embora não haja uma legislação de âmbito nacional, o judiciário tem agido e as decisões no geral têm beneficiado ao trabalhador. Das 11 reportagens que falam de decisões judiciais, cem por cento das decisões são a favor da vítima, normalmente aplicando multas nas empresas nas quais as vítimas trabalhavam.

Há matérias nesse mesmo site falando sobre o posicionamento favorável do judiciário em relação às vitimas de assédio moral. É o caso da reportagem "TRTs condenam por assédio moral" do jornal Valor Econômico, publicada no dia 27 de junho de 2005. Nessa matéria a autora da reportagem Zínia Baeta afirma que os poucos processos já julgados nos tribunais são favoráveis aos trabalhadores. Baseada no Levantamento da advogada Adriana Calvo, Baeta relata que do inicio do ano de 2005 até abril pelo menos 12 casos já tinham sido julgados e a posição foi favorável ao trabalhador em 11 desses 12 casos, tendo a empresa que pagar uma indenização. “... as empresas foram condenadas a pagar aos ex-empregados valores que variaram de $R \$ 5$ mil a $R \$ 40$ mil”, afirma a advogada Adriana Calvo.

Diante desse quadro de responsabilização das empresas, percebe-se que as mesmas têm começado a se preocupar com essa questão. No sitio eletrônico da SPM das 92 reportagens sobre assédio moral, 4 discutem a preocupação das empresas com o assédio moral. As empresas tentam de várias maneiras se resguardarem das consequiências dessa prática maldosa, seja promovendo palestras e seminários a respeito do tema, seja assinando 
apólice de seguro contra indenizações de assédio moral. Bons exemplos dessas atitudes que as empresas andam tomando são as reportagens do site da SPM: "Seminário discute assédio moral nas empresas" publicado pelo jornal Gazeta Mercantil e "Seguradora lança apólice para casos de assédio moral” do jornal Valor Econômico.

A primeira reportagem "Seminário discute assédio moral nas empresas" publicada no dia 18 de abril de 2007 mostra a preocupação de algumas empresas em evitar que essas práticas aconteçam nos seus domínios. Este seminário foi promovido pela Associação Brasileira de Bancos (ABBC), que por sinal é uma categoria que aparece muito na mídia por causa de denuncias de assédio moral, e aconteceu no dia 26 de abril na sua sede em São Paulo. A pauta do seminário era abordar as responsabilidades das organizações, os critérios de fixação de indenizações compensatórias e medidas preventivas a serem adotadas pelas empresas contra o assédio moral e sexual.

A segunda reportagem "Seguradora lança apólice para casos de assédio moral" que foi publicada no dia 28 de agosto de 2007 traz como ponto principal o surgimento da primeira apólice de seguro no Brasil para garantir o pagamento de indenizações por práticas de assédio moral no ambiente de trabalho. A repórter Luiza de Carvalho relata o crescimento das disputas judiciais envolvendo o assédio moral e acredita que por isso esse tipo de apólice deve ser bem requisitado. De acordo com Eduardo Pitombeira, diretor de seguro financeiro de Zurich, "a estimativa é a de que até o fim do ano o novo seguro de práticas trabalhistas indevidas seja vendido para cinco mil empresas no país." Para Pitombeira "a apólice foi motivada por fatores como o aumento da fiscalização nas questões de assédio moral e a conscientização dos trabalhadores."

Essa questão de uma maior preocupação por parte do judiciário também foi notada ao analisar as 92 reportagens do site da SPM. Não há uma maior preocupação somente pelo judiciário, mas também pelo legislativo. Das 92 reportagens mostradas no site citado, 8 se relacionam a proposições legislativas de novas leis sobre o assédio moral e ao debate do legislativo a respeito do tema. Acerca dessa maior preocupação do poder judiciário e do poder legislativo podem se citadas as reportagens “Assédio moral é debatido por juízes de PE” do jornal Diário de Pernambuco e "Assédio moral faz mal à saúde” do jornal Folha de Pernambuco.

A primeira reportagem "Assédio moral é debatido por juízes de PE” foi publicada no dia 7 de dezembro de 2004 e demonstra uma preocupação maior do poder judiciário com o tema. O encontro aconteceu no auditório do Tribunal Regional do Trabalho (TRT) e contou 
com a participação da Associação dos Advogados Trabalhistas (AATP) e a Associação dos Juízes Trabalhistas do Pernambuco. De acordo com o presidente da AATP, advogado Jefferson Calaço, "o encontro reveste-se da maior importância porque o assédio moral, que chega a ser mais grave do que o assédio sexual, está hoje presente em empresas públicas e particulares." Esse encontro mostra uma tentativa de articulação do judiciário com os advogados e a sociedade civil, tendo em vista que essa audiência foi aberta ao público, para tentar encontrar maneiras de combater o problema do assédio moral no trabalho.

A segunda reportagem "Assédio moral faz mal à saúde" foi publicada no dia 28 de agosto de 2006 e falava das consequiências do assédio moral na saúde do trabalhador e não somente disso, mas também, de alguns projetos que estão na Câmara dos Deputados que objetivam combater o assédio moral no trabalho. Um desses projetos é o de $n^{\circ}: 2.369 / 03$, proposto pelo deputado Mauro Passos, que é objeto deste trabalho. O deputado Mauro Passos explica "o projeto tem um lado cível e outro trabalhista porque não se pode apenas penalizar quem o pratica como também a empresa, pois acreditamos que ele (o assédio) não seja algo deslocado da gestão". Essas matérias demonstram que o legislativo percebeu a necessidade da sociedade, devido a vários motivos, e está agindo. Está agindo a seu ritmo, mas está agindo.

O último ponto que chama a atenção no total das matérias que contêm no site da SPM é a preocupação demonstrada pela mídia em esclarecer o que seria assédio moral. Das 92 reportagens sobre o assédio moral, 10 tem a intenção principal de explicar sobre o tema. Isso é positivo, pois, mostra o papel importante que a mídia desempenha e como ela pode influenciar na atitude dos trabalhadores e até na ação dos poderes judiciário e legislativo.

Assédio sexual X Assédio moral

A tabela abaixo mostra algumas diferenças trazidas pelos entrevistados entre a Lei que dispõe sobre o assédio sexual, Lei de $\mathrm{n}^{\mathrm{o}}$ : 10.224/01, e Projeto de Lei que dispõe sobre o assédio moral, Projeto de lei de $\mathrm{n}^{\mathrm{o}}: 2.369 / 03$. 


\begin{tabular}{|c|c|}
\hline Lei de $n^{0}: 10.224 / 01$ & Projeto de Lei de $n^{0}: 2.369 / 03$ \\
\hline $\begin{array}{l}\text { Criminalizou o assédio sexual tipificando } \\
\text { esse delito no código penal; }\end{array}$ & $\begin{array}{l}\text { Não criminaliza o assédio moral, mas o } \\
\text { transforma em ilícito trabalhista; }\end{array}$ \\
\hline $\begin{array}{l}\text { Prevê pena de detenção no período de } 1 \text { a } 2 \\
\text { anos; }\end{array}$ & Prevê multa; \\
\hline $\begin{array}{l}\text { Alterou o decreto lei } \mathrm{n}^{\circ}: 2.848 / 1940 \text { (código } \\
\text { penal); }\end{array}$ & $\begin{array}{l}\text { Será disciplinada pela Consolidação das Leis } \\
\text { trabalhistas (CLT); }\end{array}$ \\
\hline $\begin{array}{l}\text { Possui transversalidade de gênero na } \\
\text { justificativa do seu projeto; }\end{array}$ & $\begin{array}{l}\text { Não possui em seu texto a transversalidade } \\
\text { de gênero na justificativa do seu projeto; }\end{array}$ \\
\hline $\begin{array}{l}\text { É frequiente que uma conduta de assédio } \\
\text { sexual leve ao assédio moral. }\end{array}$ & $\begin{array}{l}\text { Não é frequiente que uma conduta de assédio } \\
\text { moral leve ao assédio sexual. }\end{array}$ \\
\hline
\end{tabular}

Tabela 1 - Comparação entre a Lei de no: 10.224/01 e Projeto de Lei de no: 2.369/03

Fonte: Elaboração própria com base nos textos consultados e na fala das entrevistadas.

A experiência deste trabalho permite visualizar que existem algumas semelhanças e diferenças entre o assédio sexual e moral, não somente no que diz respeito a Legislação, mas também, no que se refere ao processo de surgimento das mesmas. No caso do Assédio sexual, os parlamentares consideraram melhor restringir o crime, definir especificamente o que seria considerado crime, para que assim fosse possível caracterizar e punir melhor.

No caso do Assédio moral, há uma tendência oposta, o conceito se dilui e a caracterização é mais difícil, consequentemente, a punição é mais difícil. Em se tratando de punição, o assédio sexual, por ser lei e está previsto no código Penal, prevê punição mais severa, como a prisão.

No caso do projeto de Lei que prevê a punição do assédio moral, pelo fato de não pretender, o projeto de lei em questão, transformar essa prática em crime e pela dificuldade de se caracterizar essa conduta, prevê multa ao invés de prisão. Contudo, mesmo não trazendo a prisão como punição, o projeto de Lei sobre assédio moral possibilita uma responsabilização do empregador, o que contribui de alguma maneira para a visualização do problema como uma questão social e não individual, como ocorre com o assédio sexual. O assédio sexual por ser mais restrito acaba permitindo uma percepção do problema como uma questão muito 
individual, o que não corresponde com a realidade, como foi dito ao longo deste trabalho, o assédio sexual decorre de uma questão essencialmente cultural.

A mídia vem demonstrando que desempenha um papel fundamental no combate a essas duas práticas que degradam o ambiente de trabalho. Por meio de sua atuação a mídia vem evidenciando e problematizando esse tema, mostrando para as autoridades competentes, em especial o poder legislativo, a necessidade que a sociedade civil possui de que essas condutas maldosas sejam criminalizadas.

A importância da sua atuação não se restringe somente a ao fato de chamar a atenção do Poder Legislativo, mas também de trazer ao conhecimento de muitas pessoas a problemática do Assédio sexual e moral no trabalho e mostrar que esses dois pontos obscuros do mundo do trabalho são de responsabilidade das autoridades, são um assunto de saúde pública e não um problema individual, por isso, devem e precisam ser denunciados.

As denúncias das vítimas de Assédio sexual e moral também são de extrema importância, pois, como disseram os entrevistados, o Legislativo age por provocação e nesse sentido cabe a sociedade civil mostrar para o mesmo a necessidade de formulação de Leis que criminalizem essas práticas criminosas no mercado de trabalho.

A sociedade civil precisa perder o medo de falar desse assunto publicamente, as mulheres precisam romper com esse poder que os homens têm de dispor sobre o seu corpo e a sua sexualidade. As mulheres precisam se unir para superar essa divisão sexual do trabalho que se baseia no sexo biológico e que faz com que as mesmas enfrentem muitas discriminações e problemas como o Assédio sexual e moral no trabalho. 


\section{CONSIDERAÇÕES FINAIS}

Esta pesquisa buscou compreender como aconteceu o processo de surgimento da Lei que dispõe sobre o assédio sexual, Lei de $n^{\circ}$ : 10.224/01, e projeto de Lei que dispõe sobre o assédio moral, projeto de Lei de $n^{\circ}: 2.369 / 03$. Sendo assim, teve por objetivo principal investigar quais foram os fatores fundamentais para o nascimento das referidas Lei e Projeto de Lei e como eles influenciaram no decorrer do caminho que resultou na aprovação da Lei e proposição do Projeto de Lei citados. A partir desse objetivo, tomou-se como hipótese inicial de pesquisa a seguinte afirmação: A denúncia de vítimas de assédio sexual e de assédio moral foi fundamental para surgimento dessa Lei (Lei de $n^{\circ}$ : 10.224/01) e projeto de Lei (Projeto de Lei de $n^{\text {o: }}$ 2.369/03).

Contudo, chegou-se a conclusão com este estudo que diversos fatores foram fundamentais para o surgimento da referida legislação, pois, eles em conjunto formaram um contexto favorável que impulsionou o surgimento da Lei e Projeto de Lei mencionados. Sendo assim, a hipótese foi parcialmente confirmada, pois, estava incompleta na sua formulação inicial. Percebeu-se que faltaram alguns fatores que foram também fundamentais para a aprovação da Lei e para o surgimento do projeto de lei quem questão, esses fatores são: a participação dos movimentos sociais, dos movimentos feministas e do movimento de mulheres.

Nota-se pela fala das entrevistadas que esses fatores tiveram destaque dos demais e ressalta-se também que o movimento feminista tem desempenhado um papel fundamental como propulsor na conquista de muitos direitos das mulheres. No caso do Assédio sexual e moral é notório o duro trabalho do movimento feminista para a criminalização e punição dessas duas práticas cruéis.

Outra conclusão que se obteve, com a ida a campo e as dificuldades para encontrar entrevistados e dados, foi que o tema ainda não está enraizado na sociedade brasileira e nem forma parte importante da agenda política em discussão. O Estado não dispõe de muitos mecanismos para fiscalizar e/ou coibir essas práticas criminosas, tendo em vista que, além da via judicial, o único órgão que a vítima de assédio pode recorrer é a Superintendência Regional do Trabalho (SRT).

A SRT, por sua vez, somente pode fazer algo em relação ao assédio moral, pois, quando chega um caso de assédio sexual a vítima é encaminhada a Delegacia. Mesmo em 
relação ao assédio moral a SRT pouco pode fazer, porque a mesma não dispõe de meios muito eficazes para coibir essa conduta cruel.

Segundo a fala do Sr Sérgio Paulo de Almeida Santos, chefe da Seção de Políticas de Trabalho, Renda e Economia Solidária (SPTER), o único instrumento que a SRT faz uso nesses casos é um termo de compromisso, no qual o empregador se compromete a combater esse tipo de prática na sua empresa. Mas depois de assinado esse termo, não há um acompanhamento da SRT do caso e não há como saber se o empregador realmente cumpriu com o que foi assinado no termo. Além dessa limitação de competência, existe também uma limitação de mão-de-obra, pois, de acordo com o Sr. Santos a SRT sofre atualmente de uma grande defasagem de trabalhadores o que resulta no fato de não darem conta da demanda que chega até eles.

Percebe-se com este trabalho que o Estado brasileiro evoluiu em relação às práticas de assédio sexual e moral, mas, essa evolução vem ocorrendo lentamente e as custas de muita reivindicação da sociedade civil. Nota-se também, depois de se deparar com tantas dificuldades para coletar dados, a necessidade de uma maior transparência e uma melhor sistematização dos dados sobre as denúncias de assédio moral e sexual. É preciso que haja uma punição para os dois tipos de assédio, é necessário que o projeto de Lei sobre assédio moral seja aprovado.

Os problemas do assédio sexual e moral, como já foi dito ao longo do trabalho, possuem uma ligação com a questão da discriminação no mercado de trabalho e raízes nas questões culturais. Sendo assim, o combate a essas condutas maldosas vai além da criminalização das mesmas, necessita também de uma união de ações que envolvam a política social, política de gênero e política de trabalho. Na realidade, qualquer ação que busca reduzir as desigualdades em determinado contexto feminino precisa de uma atuação conjunta dessas políticas. A política social atua de uma maneira mais ampla tentando garantir os mínimos sociais, e a políticas de trabalho e gênero devem atuar de maneira articulada para possibilitar uma autonomia do sujeito no sentido de que este não venha sobrecarregar a primeira política. Só com políticas eficientes de gênero e de trabalho as mulheres poderão obter independência e poderão lutar para contra com o domínio masculino que perpassa todos os âmbitos da vida das mulheres. 


\section{REFERÊNCIAS BIBLIOGRÁFICAS}

ARAÚJO, Clara e SCALON, Celi (Org.). Gênero, família e trabalho no Brasil. Rio de Janeiro: Editora FGV, 2005.

ARroio, Ana e RÉGIGNIER, Karla. O Novo Mundo do Trabalho: Oportunidades e

Desafios para o Presente. Disponível em: http://www.senac.br/BTS/272/boltec272d.htm .

Acesso em 10 de agosto de 2010.

BRANCO, Ana Paula Tauceda e RODRIGUES, Natália Mara Silva. O crime do assédio sexual no meio-ambiente do trabalho: uma abordagem principiológica constitucional. Disponível em: http://www.amatra17.org.br/arquivos/4a4a89850220a.pdf . Acesso em 12 de abril de 2010.

BOSCO, Maria Goretti DaI. Assédio sexual nas relações de trabalho. Disponível em: http://www.buscalegis.ufsc.br/revistas/files/journals/2/articles/10687/public/10687-10687-1PB.pdf . Acesso em 06 de novembro de 2009.

BRASIL. Constituição da República Federativa do Brasil. Brasília: Senado Federal, 1988.

BRASIL. Decreto-Lei no $\mathbf{2 . 8 4 8}$, de 7 de dezembro de 1940. Código Penal. Publicado no Diário Oficial da União (DOU) de 31 de dezembro de 1940 e retificado no Diário Oficial da União (DOU) de 3 de janeiro de 1941.

BRASIL. Decreto-Lei $n^{\circ}$ 5.452, de $1^{\circ}$ de maio de 1943. Aprova a Consolidação das Leis do Trabalho. Publicado no Diário Oficial da União (DOU) de 9 de agosto de 1943.

BRASIL. Lei $\mathrm{n}^{\circ} \mathbf{1 0 . 2 2 4}$ de 15 de maio de 2001. Altera o Decreto-Lei $\mathrm{n}^{\circ} 2.848$, de 7 de dezembro de 1940-Código Penal, para dispor sobre o crime de assédio sexual e dá outras providências. Publicado no Diário Oficial da União (DOU) de 16 de maio de 2001.

BRASIL. Projeto de lei $\mathbf{n}^{\mathbf{0}} \mathbf{2 . 3 6 9 / 0 3}$. Define o assédio moral e prevê responsabilidade do empregador no tocante as providências para evitar o assédio. Está tramitando no Congresso Nacional e atualmente está sob relatoria do deputado Vicentinho (PT/SP), na Comissão de Trabalho. Depois, vai ao exame da Comissão de Constituição e Justiça.

BOURGUIGNON, Jussara Ayres. A particularidade histórica da pesquisa no Serviço Social. Rev. katálysis [online]. 2007, vol.10, n.spe, pp. 46-54. Disponível em: http://www.scielo.br/pdf/rk/v10nspe/a0510spe.pdf . Acesso em 02 de setembro de 2010.

CANIATO, Angela M. Pires \& LIMA, Eliane da Costa. Assédio moral nas organizações de trabalho: perversão e sofrimento. Disponível em: http://pepsic.bvspsi.org.br/pdf/cpst/v11n2/a04v11n2.pdf . Acesso em 16 de outubro de 2009.

CARLOTO, Cassia Ma. O conceito de gênero e sua importância para a análise das relações sociais. Serviço Social em Revista, v.3, num. 2, Jan/Jun, 2001. Disponível em: http://www.ssrevista.uel.br/n2v3.pdf\#page=83. Acesso em: 15 de outubro de 2009. 
CHIZZOTTI, Antônio. A pesquisa qualitativa em ciências humanas e sociais: evolução e desafios. Disponível em: http://redalyc.uaemex.mx/pdf/374/37416210.pdf . Acesso em 20 de junho de 2010.

COSTA, Sílvia Generali da. Assédio sexual - uma versão brasileira. Porto Alegre: Artes e Ofícios Editora LTDA, 1995.

CRUZ, Andréia da et. al. Violência contra a mulher: O surgimento da Lei Maria da Penha Lei 11 340/06. Relatório de Pesquisa apresentado à disciplina Pesquisa em Serviço Social 2. Brasília: Universidade de Brasília, 2008 (mimeo).

FREITAS, Maira Ester de. Assédio moral e Assédio sexual: faces do poder perverso nas organizações. Disponível em: http://www.ipea.gov.br/ouvidoria/doc/Maria_Ester_de_Freitas.pdf . Acesso em: 06 de novembro de 2009.

GOVERNO FEDERAL, Secretaria de Assuntos Estratégicos da Presidência da República. Comunicados do Ipea: $\mathbf{N}^{\mathbf{0}} \mathbf{4 0}$ Mulher e Trabalho: Avanços e continuidades. Disponível em http://agencia.ipea.gov.br/images/stories/PDFs/100308_comu40mulheres.pdf . Acesso em 25 de julho de 2010.

GOVERNO FEDERAL, Secretaria de Assuntos Estratégicos da Presidência da República. Texto para discussão no 473 do Ipea: Modernização Produtiva e Relações de Trabalho: Perspectivas de Políticas Públicas. Disponível em: http://desafios.ipea.gov.br/pub/td/1997/td_0473.pdf. Acesso em 10 de setembro de 2010.

GUNTHER, Hartmut. Pesquisa qualitativa versus pesquisa quantitativa: Esta é a Questão? Disponível em: http://www.scielo.br/pdf/ptp/v22n2/a10v22n2.pdf . Acesso em 20 de junho de 2010.

HELOANI, Roberto. Assédio moral: a dignidade violada. Disponível em: http://pepsic.bvspsi.org.br/pdf/aletheia/n22/n22a10.pdf. Acesso em 06 de novembro de 2009.

HIRATA, Helena. Wanda Caldeira Brant (trad.) Nova divisão sexual do trabalho? Um olhar voltado para a empresa e a sociedade. $1^{\text {a }}$ Ed. São Paulo: Boitempo Editorial, 2002.

HIRATA, Helena \& KERGOAT, Danièle. Novas configurações da divisão sexual do trabalho. Disponível em: http://www.scielo.br/pdf/cp/v37n132/a0537132.pdf . Acesso em 16 de outubro de 2009.

HIRIGOYEN, Marie-France. Assédio Moral: a violência perversa no cotidiano. Rio de Janeiro: Bertrand Brasil, 2002.

HIRIGOYEN, Marie F. Mal estar no trabalho: redefinindo o Assédio Moral. $3^{\text {a }}$ Ed. Rio de Janeiro: Bertrand Brasil, 2006.

LIPPMAN, Ernesto. Assédio sexual nas Relações de Trabalho: danos morais e materiais nos Tribunais após a lei $\mathbf{n}^{\mathbf{0}} \mathbf{1 0 . 2 2 4}$. São Paulo: LTr, 2001. 
LOPES, Carina. O assédio sexual e o assédio moral na visão do direito do trabalho. Disponível em: http://www.buscalegis.ufsc.br/arquivos/O\%20ass\%E9dio\%20sexual\%20e\%20o\%20ass\%E9di o\%20moral\%20na\%20vis\%E3o\%20do\%20direito\%20do\%20trabalho.pdf . Acesso em 5 de março de 2010.

MARCONI, Marina de Andrade \& LAKATOS, Eva Maira. Técnicas de pesquisa. $3^{\text {a }}$ Ed. São Paulo: Editora Atlas S.A., 1996.

MOREIRA, Marilda M. da Silva. Assédio sexual feminino no mundo do trabalho: algumas considerações para reflexão. Disponível em: http://www.ssrevista.uel.br/c_v4n2_marilda.htm. Acesso em 06 de novembro de 2009.

NEVES, Jose Luis. Pesquisa qualitativa - Características, usos e possibilidades. Disponível em: http://www.ead.fea.usp.br/cad-pesq/arquivos/c03-art06.pdf . Acesso em 20 de junho de 2010.

NOGUEIRA, Claudia M. A feminização no mundo do trabalho: entre a emancipação e a precarização. Campinas, SP: Autores Associados, 2004.

PAMPLONA FILHO, Rodolfo. Assédio sexual: questões conceituais. Disponível em: http://www.prt18.mpt.gov.br/eventos/2004/saude_mental/anais/artigos/14.pdf . Acesso em 10 de maio de 2010.

SOUZA, Terezinha M. dos Santos. Assédio moral e Assédio sexual: interfaces. Disponível em: http://www.interfacehs.sp.senac.br/images/artigos/170_pdf.pdf . Acesso em 06 de novembro de 2009.

SOUZA, Vera Lúcia de. A qualificação do conceito assédio moral no Brasil. Disponível em: http://www.dominiopublico.gov.br/download/texto/cp103286.pdf . Acesso em 04 de julho de 2010.

YANNOULAS, Silvia C. A convidada de pedra - Mulheres e Políticas Públicas de Trabalho e Renda. Brasília: FLACSO/Abaré, 2003.

ZANETTI, Robson. Assédio moral no trabalho. Disponível em: http://www.robsonzanetti.com.br/v3/docs/livro_robson_zanetti_assedio_moral.pdf . Acesso em 10 de dezembro de 2009.

\section{Sites Consultados:}

www.presidencia.gov.br

www.sepm.gov.br

www.observatoriodegenero.gov.br 
APÊNDICES

APENDICE I

OFICÍO DE APRESENTAÇÃO

Universidade de Brasília-UnB

Instituto de Ciências Humanas-IHD

Departamento de Serviço Social-SER

Ofício $n^{\circ} 120$

Brasília, dezembro de 2009.

Senhor (a) responsável pela Delegacia Regional do Trabalho,

Solicitamos a Vossa Senhoria autorização para que a aluna Andréia da Cruz, matrícula 06/79275, aluna regular do Curso de Serviço Social do Departamento de Serviço Social da Universidade de Brasília, matriculada na disciplina: Trabalho de Conclusão de Curso, sob a orientação da Professora Dr $^{\mathrm{a}}$ Silvia Cristina Yannoulas, possa realizar pesquisa nessa Instituição.

Tais informações revertem-se de grande importância para elaboração da Monografia de conclusão do Curso de Graduação.

Colocamo-nos a disposição para maiores esclarecimentos.

Respeitosamente,

Prof. ${ }^{\text {a }} \mathrm{Dr}^{\mathrm{a}}$ Silvia Cristina Yannoulas

Responsável pela disciplina - SER/IHD/UnB

Telefones: (61) 3307-2290, 3307-2770 e 3307-2772 


\section{APENDICE II TERMO DE CONSENTIMENTO LIVRE ESCLARECIDO (TCLE)}

O senhor (a) está sendo convidado (a) a participar da pesquisa intitulada "Assédio Sexual e Moral no trabalho: Um estudo acerca da legislação no Brasil”. O projeto de pesquisa corresponde ao trabalho de conclusão de curso pelo Departamento de Serviço Social da Universidade de Brasília. A pesquisa tem por objetivo descobrir quais foram os fatores fundamentais para o surgimento da Lei $\mathrm{n}^{\circ}$ : 10.224/01 e projeto de Lei $\mathrm{n}^{\mathrm{o}}: 2.369 / 03$, que regulam respectivamente o assédio sexual e o assédio moral. É também um dos interesses desta pesquisa estudar os possíveis casos e situações que deram visibilidade ao assunto na mídia, percebendo a multiplicidade de fatores que formam todo o conjunto do processo que foi o surgimento da referida legislação. Tendo conhecimento do que trata o projeto de pesquisa acima descrito, concordo em participar voluntariamente - sendo que o (a) participante pode desistir de continuar a qualquer momento sem riscos de ser penalizado (a) pela instituição local de estudos. Além disso, o (a) participante pode se recusar a responder questões que lhes tragam constrangimento. Os dados da pesquisa serão utilizados para desenvolver o trabalho de conclusão do curso e serão apresentados para a banca examinadora do Departamento de Serviço Social, sendo que o material coletado durante a pesquisa estará sob responsabilidade do (a) pesquisadora responsável e da assistente de pesquisa. A pesquisadora responsável estará disposta a qualquer esclarecimento antes, durante e depois da entrevista.

Dados do (a) Participante:

Nome

Assinatura do (a) participante da pesquisa

Pesquisadora responsável: Silvia Cristina Yannoulas

Instituição procedente da pesquisadora: Departamento de Serviço Social da Universidade de Brasília.Telefones: (61) 3307-2290, 3307-2770 e 3307-2772

Brasília de de 2010.

Assinatura do (a) pesquisador (a) responsável 
APENDICE III

GUIA DE ENTREVISTA SEMI-ESTRUTURADA 1

\section{Roteiro de enunciados:}

1. Como surgiu a iniciativa de criação da Lei $n^{\circ}: 10.224 / 01$ que introduziu no Código Penal o delito de assédio sexual?

2. E no caso do projeto de Lei $n^{\circ}: 2.369 / 03$ que normatiza o assédio moral e prevê a responsabilização do empregador?

3. Qual seria a diferença entre os dois tipos de iniciativa?

4. Por que as diferenças na maneira de iniciar o processo?

5. Quem foram os atores principais nesse processo? os movimentos sociais?, o governo? as vítimas com suas denúncias? outros atores?

6. Quais foram os fatores que contribuíram para o surgimento ou aprovação dessa legislação?

7. Dentre esses fatores, quais você considera que foram fundamentais para o surgimento dessa Lei e referido processo de lei?

8. Por que você atribui a esses fatores citados acima importância fundamental no processo de surgimento dessa legislação?

9. Houve fatores que atrapalharam o desenrolar desse processo? Se houve, quais foram?

10. A senhora poderia indicar mais alguém para ser responder a essas mesmas perguntas, alguém que pudesse contribuir significativamente para esta pesquisa concedendo informações a respeito do tema tratado? 


\section{APENDICE IV}

GUIA DE ENTREVISTA SEMI-ESTRUTURADA 2

\section{Roteiro de enunciados:}

1- Qual é o posicionamento da (nome da instituição) sobre as dificuldades que as mulheres enfrentam no mercado de trabalho, como por exemplo: maior dificuldade de conseguir emprego, menores salários, menores possibilidades de ascensão?

2- Quais os fatores que a (nome da instituição) considera como causas de todas essas barreiras que as mulheres enfrentam no mercado de trabalho?

3- Os fatores citados acima se relacionam de alguma maneira as práticas de assédio sexual e moral que acontecem no ambiente de trabalho?

4- Qual é o posicionamento da (nome da instituição) em relação às práticas de assédio sexual e assédio moral tão freqüentes no dia-a-dia dos trabalhadores e das trabalhadoras brasileiras?

5- A (nome da instituição) tem estudos sobre essas práticas no Brasil? Saberia informar sobre qual gênero (mulheres ou homens) recai mais o assédio sexual e o assédio moral?

6- Há autores que afirmam que o assédio moral às vezes decorre de um assédio sexual mal sucedido. Qual o posicionamento da (instituição) sobre isso? A (instituição) consegue visualizar uma transversalidade de gênero no assédio moral?

7- Qual o posicionamento da (nome da instituição) em relação à legislação brasileira acerca desses temas. A (instituição) considera que o governo tem atuado de maneira eficiente pra coibir essas práticas?

8- Em relação à "relativa demora" do país em criar uma legislação que criminalizasse essas práticas, qual o entendimento da (nome da instituição) em relação a isso? A que se deve essa demora?

9- A entrevistada poderia indicar mais alguém para ser responder a essas mesmas perguntas, ou perguntas mais relacionadas com o surgimento das legislações sobre assédio sexual e assédio moral? Alguém que pudesse contribuir significativamente para esta pesquisa concedendo informações a respeito do tema tratado? 


\section{APENDICE V \\ GUIA DA PESQUISA DOCUMENTAL}

- Após um levantamento bibliográfico, se dará prosseguimento ao levantamento de reportagens contidas em jornais, revistas e periódicos eletrônicos de maior conhecimento da população, estas que se relacionem ao tema proposto;

- Em seguida se fará um levantamento reportagens contidas em jornais, revistas e periódicos impressos maior conhecimento da população, estas que se relacionem ao tema proposto;

- Depois se selecionará as principais reportagens encontradas para que se dê a análise do conteúdo que elas trazem, identificando fatos, pessoas, acontecimentos que subsidiem a comprovação ou refutação da hipótese proposta. 